\title{
WestVirginiaUniversity
}

THE RESEARCH REPOSITORY @ WVU

Graduate Theses, Dissertations, and Problem Reports

2001

\section{Valuation of electric utility generating assets in a competitive environment}

Mary Barbara Cain

West Virginia University

Follow this and additional works at: https://researchrepository.wvu.edu/etd

\section{Recommended Citation}

Cain, Mary Barbara, "Valuation of electric utility generating assets in a competitive environment" (2001). Graduate Theses, Dissertations, and Problem Reports. 1278.

https://researchrepository.wvu.edu/etd/1278

This Thesis is protected by copyright and/or related rights. It has been brought to you by the The Research Repository @ WVU with permission from the rights-holder(s). You are free to use this Thesis in any way that is permitted by the copyright and related rights legislation that applies to your use. For other uses you must obtain permission from the rights-holder(s) directly, unless additional rights are indicated by a Creative Commons license in the record and/ or on the work itself. This Thesis has been accepted for inclusion in WVU Graduate Theses, Dissertations, and Problem Reports collection by an authorized administrator of The Research Repository @ WVU. For more information, please contact researchrepository@mail.wvu.edu. 
Valuation of Electric Utility Generating Assets in a Competitive Environment by

\author{
Mary B. Cain
}

Thesis

Submitted to the College of Agriculture, Forestry and Consumer Sciences At West Virginia University

In partial fulfillment of the requirements for the degree of

Master of Science in Agricultural and Resource Economics

\author{
Thomas F. Torries, Ph.D., Co-Chair \\ Jerald J. Fletcher, Ph.D., Co-Chair \\ Gerard E. D'Souza, Ph.D. \\ Alan R. Collins, Ph.D.
}

Department of Agricultural and Resource Economics Morgantown, WV

Keywords: Electricity deregulation, property taxation, asset valuation methods 


\section{ABSTRACT \\ Valuation of Electric Utility Generating Assets in a Competitive Environment}

Mary B. Cain

Electricity industry restructuring, technological advances, and changing environmental laws and regulations are providing opportunities for many electricity companies to substantially lower their cost of doing business. One such cost is property tax, which in a majority of states is based upon the fair market value of property. Traditionally, assets of a regulated utility were valued at fair market value based upon the regulated price of electricity or "rate base". The use of rate bases as benchmarks for valuation of assets is quickly becoming irrelevant. Valuation methods such as the income approach, replacement cost approach, comparable sales approach, and the stock \& debt approach are common assessment methods for property tax (ad valorem) purposes. In this research, data are provided by the West Virginia state tax office, public testimony, and the Energy Information Administration. The appropriateness of each valuation method is examined for the purpose of valuing electricity generation assets in a competitive environment. The ability of companies to compete across state lines will depend on their costs. Different states employ different methods of valuation. Some states do not tax intangible property and most valuation methods include intangible property value. This aspect is addressed in the different valuation methods. The income approach to valuation is probably the best approach from the standpoint of the utility because it reflects the company's ability to compete. For the purpose of purchasing a power plant, the comparable sales approach is best while the replacement cost provides the best-cost estimate for new technology. The comparable sales approach would provide the largest amount of tax revenue. The stock and debt approach would be more reliable if not for the lack of consistent and viable market trading. 


\section{Acknowledgements}

The completion of this thesis would not have been possible without the assistance and encouragement of many people. First, I would like to thank my family and friends who have given me the necessary support throughout my graduate studies. I would especially like to thank my husband, Gregory, who has been ever patient with me and provided unwavering support without question or doubt as to my abilities.

I would especially like to thank my committee chair, Dr. Tom Torries, for his guidance, support and insight into the economic aspects of the energy industry. Without his industry and academic experience I would not have been able to appropriately explore such a complicated issue. This was especially important due to the lack of professional literature concerning deregulation, valuation, and taxation. In addition, I would also like to thank my other committee members, Dr. Gerard D’Souza, Dr. Alan Collins, and Dr. Jerald Fletcher for their patience, support and guidance.

I would also like to thank all the rest of the Resource Management faculty and staff for their support, concern and above all their good nature toward the student population. And to Dr. Jerry Fletcher who has provided me continued financial support while completing my thesis work. And to all the students that I have shared my time with, Sarah, Kathleen, Dan, Elyce, Huilan Li and many others who have passed through this department. Without the support of these people I have mentioned the successful completion of this thesis would not have been possible. 


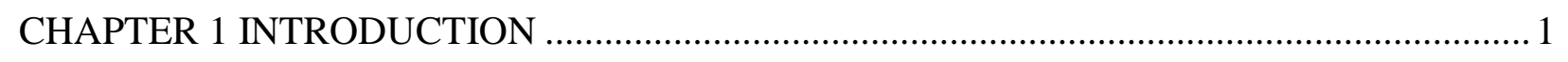

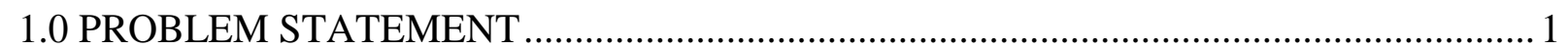

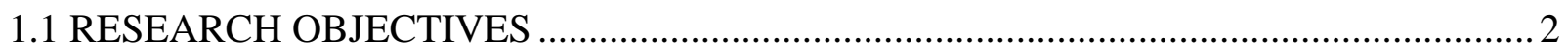

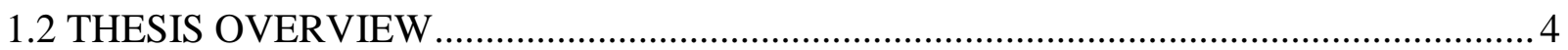

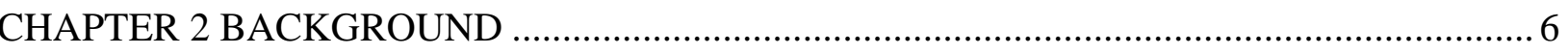

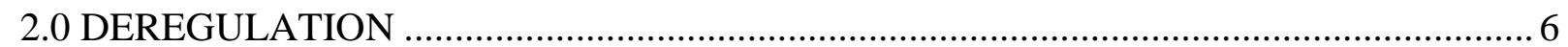

2.1 PROPERTY VALUATION............................................................................

2.2 VALUATION IN A COMPETITIVE ENVIRONMENT ............................................. 9

2.3 TYPES OF ELECTRICITY PROVIDERS AND RELATED TAX ISSUES .................... 10

CHAPTER 3 LITERATURE REVIEW ……………................................................ 13

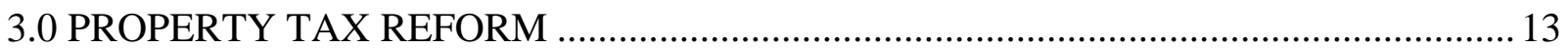

3.1 VALUATION METHODS FOR DEREGULATED ELECTRICITY GENERATORS ....14

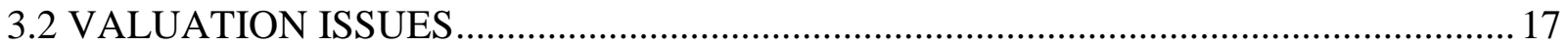

3.3 STATE TAXATION ISSUES .............................................................................. 24

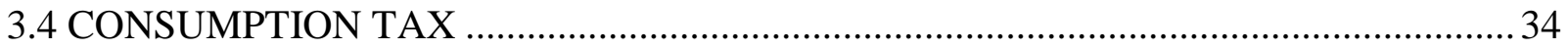

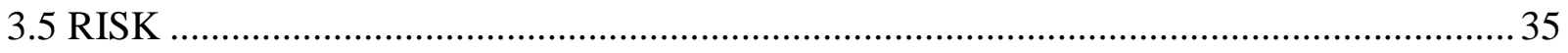

CHAPTER 4 THEORY ........................................................................................... 37

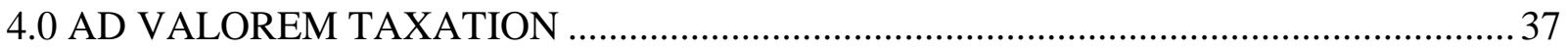

4.1 LOCATION THEORY .......................................................................................... 39

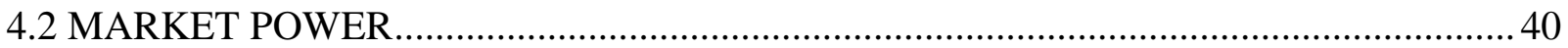

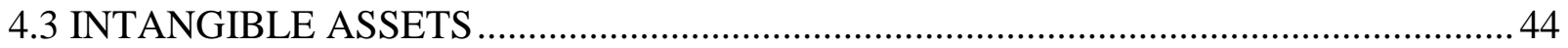

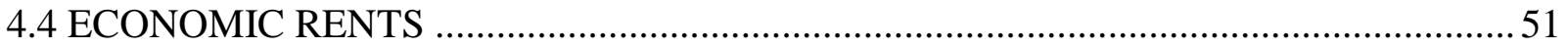

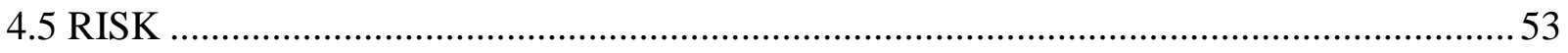

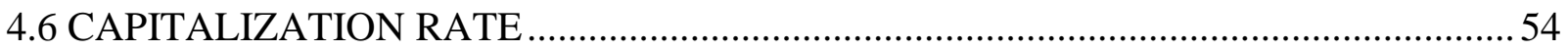

CHAPTER 5 ASSET VALUATION METHODS …….......................................................5

5.0 BASICS OF ASSET VALATION …….............................................................5

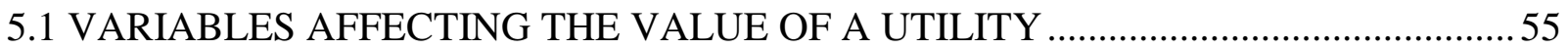

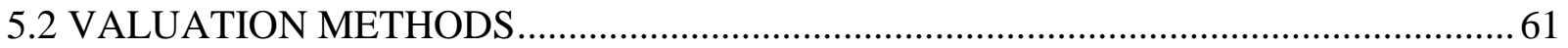

5.2.1 COST APPROACH.............................................................................. 61

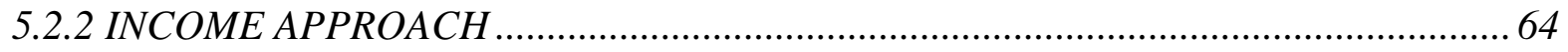

5.2.3 COMPARABLE SALES APPROACH......................................................... 71

5.2 .4 STOCK AND DEBT APPROACH ................................................................. 74

CHAPTER 6 POWER PLANT VALUATION ................................................................ 78

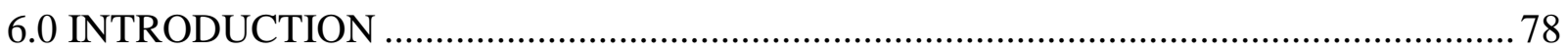

6.1 VALUATION OF APPALACHIAN POWER PLANTS IN WEST VIRGINIA ................78

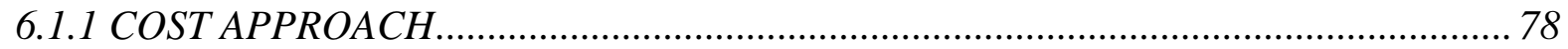

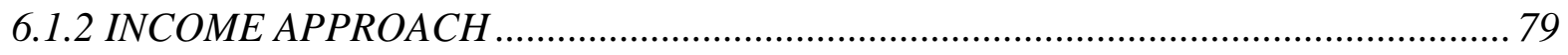

6.1.3 STOCK AND DEBT APPROACH ................................................................ 81

6.2 CURRENT APPALACHIAN POWER VALUES ...................................................... 82 
6.3 COMPARABLE SALES AND REPLACEMENT COST APPROACHES .....................83

6.3.1 COMPARABLE SALES ..................................................................................... 83

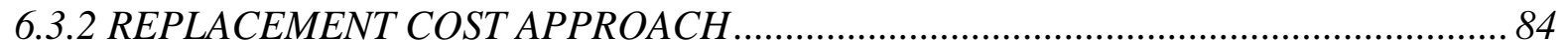

6.4 SUMMATION OF VALUES .................................................................................. 85

CHAPTER 7 SUMMARY \& CONCLUSIONS ...................................................................... 87

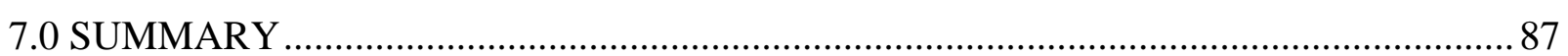

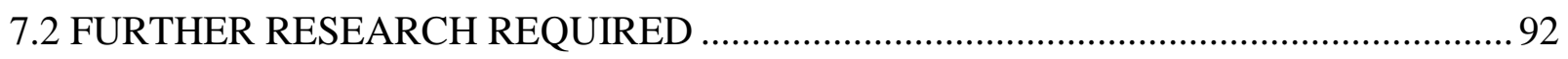

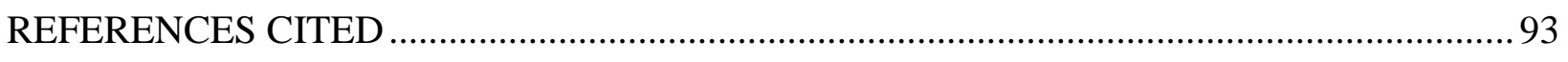


TABLE 3.1. TAX REVENUE LOSS FROM OHIO UTILITIES 32

\begin{tabular}{|rr|}
\hline TABLE 3.2. OHIO UTILITY TAX BURDEN & 33 \\
\hline
\end{tabular}

\begin{tabular}{|rr}
\hline TABLE 4.1. INTANGIBLE ASSETS & 49 \\
\hline
\end{tabular}

\begin{tabular}{|rr}
\hline TABLE 5.1. CAPITALIZATION RATE & 60 \\
\hline
\end{tabular}

\begin{tabular}{|rr}
\hline TABLE 6.1. COST APPROACH FOR AP ASSETS & 79 \\
\hline
\end{tabular}

\begin{tabular}{|rr}
\hline TABLE 6.2. INCOME APPROACH FOR AP ASSETS & 80 \\
\hline
\end{tabular}

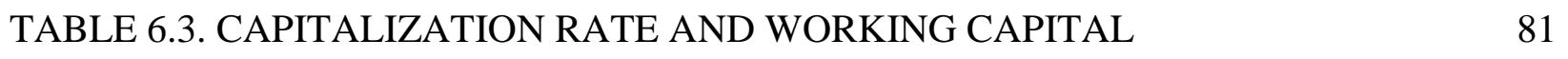

\begin{tabular}{|lr}
\hline TABLE 6.4. STOCK \& DEBT APPROACH FOR AP ASSETS & 82 \\
\hline
\end{tabular}

\begin{tabular}{|lr}
\hline TABLE 6.5. COMPARABLE SALES APPROACH FOR AP ASSETS & 84 \\
\hline
\end{tabular}

\begin{tabular}{|rr}
\hline TABLE 6.6. REPLACEMENT COST APPROACH FOR AP ASSETS & 85 \\
\hline
\end{tabular}

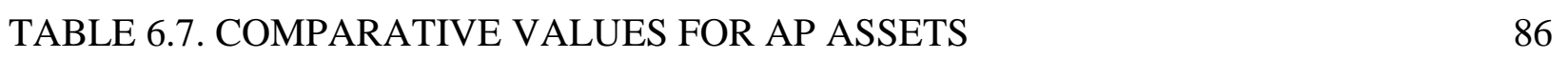




\section{List of Abbreviations}

AEP

AP

CAPM

CCGT

DCF

DFB

DOE

EEI

EIA

FERC

FMV

GCV

IOU

MV

NPV

PUC

PUHCA

PURPA

PSNH

ROI

RCNLD

TVA

WACC
American Electric Power

Appalachian Power

Capital asset pricing model

Combined-cycle gas turbine

Discounted cash flow

Discounted future benefits

Department of Energy

Edison Electric Institute

Energy Information Administration

Federal Energy Regulatory Commission

Fair market value

Going concern value

Investor owned utility

Market value

Net present value

Public Utility Commission

Public Utility Holding Company Act

Public Utilities Regulatory Policy Act

Public Service New Hampshire

Return on investment

Replacement cost new less depreciation

Tennessee Valley Authority

Weighted average cost of capital 


\section{Chapter 1}

\section{Introduction}

\subsection{PROBLEM STATEMENT}

Restructuring, technology, and environmental factors have created reasons and opportunities for electric utilities to lower their property taxes, which often make up a substantial cost of doing business. Property tax valuation is not a straightforward activity. Most states compute property taxes on the basis of "fair market value" (FMV) or what a hypothetical buyer and seller would agree the property is worth with both parties having knowledge of the relevant facts and neither compelled to buy or sell (Hayward and Schmidt, 1999). The property tax burden for electric utilities is significant but they have been allowed to recover these taxes in their rate base. Historically, the cost approach valuation method was used to establish property values for electric utilities. Thus, a regulated utility became guaranteed tax collectors for state and local governments. Local governments and school districts benefited from these property taxes. With deregulation, this traditional approach to property valuation will have to change and new methods of valuation applied. This could mean a significant reduction in property tax revenue for school districts. In Pennsylvania several court cases involving school districts and property assessment boards have occurred where school boards have appealed for utilities' assets to be valued based on a comparable sales approach. This approach would guarantee a continued high level of tax revenue as utilities move from a regulated to a deregulated environment. The problem with the cost approach is that in today's transitional market power plant sale prices tend to be overvalued. This is due to the anticipation by investors of capturing more of the power market share and anticipated earnings. 
In March 1998 the legislature enacted HB 4277, which authorizes the Public Service Commission (PSC) to develop a deregulation plan if the PSC finds that retail choice is in the public interest. Included in the public interest principles are preserving tax revenues for state and local government, no shifting of the tax burden and a tax system that does not place any competitor at a disadvantage (American Public Power Association, 2000). Then, in March 2000, the West Virginia Legislature passed HCR 27, which approves the PSC restructuring plan for deregulation. However, the resolution does not allow the plan to take effect until tax changes are made. The PSC will propose tax legislation, which the legislature is to consider in its 2001 season.

This thesis addresses different valuation methods since the rate base of a regulated utility will become irrelevant in a competitive market and the cost approach to valuation will no longer apply. The demise of rate regulation will cause some states using unit valuations to shift to valuations of individual plants. In order to determine fair market value (FMV), many valuation issues will have to be resolved by the courts to include the influence of above-market power purchase contracts on plant value, recovery of stranded costs, and the continued legitimacy of the unit approach to value. Currently, West Virginia (WV) utilizes the unit value method and the income approach. New approaches to valuation could mean significant loss of tax revenues for WV school districts. WV is currently studying the tax revenue issue as it applies to proposed electricity restructuring plans.

\subsection{RESEARCH OBJECTIVES}

Economic theory, asset valuation methods, and competitive market conditions are addressed in this thesis relative to electricity generation in a competitive environment. Current 
asset valuation methods examined in this thesis are concerned with property appraisal for ad valorem tax ${ }^{1}$ purposes. These four methods include replacement cost, income approach, comparable sales approach, and the stock \& debt approach. The cost approach applied to a regulated utility is used as a comparison. One of the key discriminators in valuing electricity generation plants is the fact that some states consider intangible property non-taxable. This is important in choosing the proper valuation method. Currently, with restructuring taking place in many states, school districts stand to lose tax revenues. Regulated electricity generators were essentially tax collectors for the state as this cost was incorporated into their rate base and added to the cost of electricity.

A competitive environment will exist across state boundaries as electricity producers attempt to increase their customer base. An important aspect of competitiveness is costs. An instate power plant may not be able to compete with out of state providers if out of state providers have lower costs. Costs can be affected by property assessments. Many states are addressing the tax revenue issue to achieve tax neutrality. This may require legislatively amending their property valuation methods. Successful competition can only be achieved if there is a "level playing field". A "level playing field" refers to tax treatment in bordering states that is equivalent in its property tax methods and assessments to surrounding states. States that tax intangible property will tend to have higher valuations for their power plants if they use such methods as comparable cost since this method is based on current market sales and also includes intangible value. The comparable sales method is the valuation method advocated by school districts, as it will result in higher revenues.

Valuation of electric utilities and their assets is important to many audiences. Utility stockholders may be concerned about the sale of utility assets at prices below the utility's

\footnotetext{
${ }^{1}$ Ad Valorem refers to that portion of value that is used for property tax purposes as a percentage of that value.
} 
balance sheet (book value). This is often known as "stranded assets". A stranded asset is the difference between a utility's value as recorded in the books versus its market value. Decisions about who absorbs or pays for these possible losses are of great concern. State legislators are also concerned about the effect of deregulation on utility prices to customers. They are simultaneously concerned with loss of tax revenue and the ability of the electricity generator to compete.

The debate concerning restructuring is underway in many states. This thesis presents a case study designed to identify those valuation issues that are related to the different methods of valuation.

\subsection{THESIS OVERVIEW}

This thesis is presented in seven chapters beginning with this introduction. The thesis presents a case study of West Virginia (WV) Appalachian Power (AP) assets to emphasis the different approaches to valuation and use the AP case for comparison. A brief description of the remaining chapters follows.

Chapter 2 consists of background information on utility deregulation and the problems associated with valuation and property taxation. The valuation methods used during regulation and the need to review current and alternative methods of valuation and taxation are discussed.

A literature review is contained in Chapter 3. An extensive review of the professional literature revealed that information in this area is lacking. Most information was obtained from special studies and reports from government agencies. Professional journals in accountancy and taxation were consulted. A review of state taxation issues that arise from tax revenue loss is also included. 
Chapter 4 addresses economic and valuation theory to support the basic principles underlying valuation methods and competitive market forces. Current methods of valuation apply to regulated electric utilities while the alternative valuation approaches addressed in this thesis concern a deregulated industry.

A discussion of the four valuation methods is contained in Chapter 5. Chapter 6 presents an application of these four methods to AP plants that operate in West Virginia. Chapter 7 is summary and conclusions of the appropriateness of the different valuation methods and the problems associated with them. Further research is advised. 


\section{Chapter 2}

\section{Background}

\subsection{DEREGULATION}

The Federal Energy Regulatory Commission (FERC) issued Order \#888 and \#889 in August of 1996 calling for wholesale competition in the electricity generation sector. In some states, retail electricity customers can now choose their electricity company. New wholesale electricity trading markets, which were previously nonexistent, are now operating in many regions of the country. The number of independent power producers and power marketers competing in these new retail and wholesale power markets has increased substantially over the past few years. To better support a competitive industry, the power transmission system is being reorganized from a system with many transmission system operators to one where only a few organizations operate the system. (EIA, 2000)

The introduction of competition has not been without its problems. California introduced retail competition in 1998 and is experiencing power shortages along with increased fuel prices. Although other states like New Hampshire and Pennsylvania have not been experiencing the problems of California's market, the lessons learned in California should not be overlooked. California's problems involve supply and demand issues, continued regulation of customer prices, and rising fuel costs. As of spring 2001, the state of WV has adopted an electricity restructuring plan but is holding off until further research is conducted. One of the areas for research is the tax revenue issue. (State electricity profiles, 2000)

During the era of regulation, electric utility companies became vertically integrated and were granted predefined and exclusive territories for providing electricity at a regulated rate of 
return on invested capital. Vertically integrated means that the same entity owns and operates all three basic functions of generating, transmitting, and distributing electricity to customers. The restructuring of the utility industry consists of deregulating the generation activities of electricity supply. Major issues surrounding the deregulation of electricity generation involve open access, competitive dispatch, retail wheeling, divestitures, mergers and acquisition, privatization, universal service, municipalization, and stranded assets.

\subsection{PROPERTY VALUATION}

While the concept is straightforward, determining fair market value can be difficult. Several valuation methods are used to estimate fair market value. They consist of the income approach, replacement cost, stock and debt approach, and the sales comparison approach. Changes anticipated in the electric industry as a result of restructuring will redefine the traditional connection between property valuation and the utility base rate, the traditional method by which utilities and local governments have calculated property taxes in the past. Deregulation will affect earnings, which will impact rate base and the method of asset valuation. Advances in natural gas turbine technology will force a re-evaluation of the cost, efficiency, and capability of existing plants. According to the Energy Information Administration (EIA, 2000), gas turbine technology has traditionally been utilized to meet excess capacity demands. The recent trend in new power plant construction has been the utilization of gas turbines for primary power

production. The prospect of new environmental legislation and regulation, coupled with deregulation, means the end of the captive market (ratepayers) through which compliance and abatement costs were recovered. While these changes will affect future adjustments in tax 
assessments, they will also affect investor expectations and the value of generation facilities. (Schneider, 1998).

Assets are valued differently in regulated and competitive environments. In a pure regulated environment, an asset's market value will equal its book value. Regulated prices are set to recover costs, pay debt, and provide a reasonable return to shareholders. In principle, the future revenues from an asset should equal the investment made in the asset plus the shareholder's return on investment (ROI). Regulators in most jurisdictions use original cost methods to determine the value of a utility's assets (Bonbright, Danielson, and Kamerschen, 1988). Public utilities may recover only the asset's original cost through rates. Book value is simply an asset's original cost minus depreciation.

In a competitive environment, the value of an asset equals the expected present value of the profits an asset can generate under its best use. (Copeland and Murin, 1990). Asset value is directly related to the market price that can be obtained for the goods or services that the asset produces. Value is not fixed but changes over time in response to market conditions. In competitive markets, the prices of services that flow from an asset are determined by numerous exchanges between willing buyers and willing sellers. Economic theory tells us that in perfectly competitive markets, efficient resource allocation criteria are met when the price of a good or service equals its marginal production cost. Yet these marginal-cost-based prices may have no relationship to the historical average costs of individual firms. At a given equilibrium price, some firms may enjoy temporary profits, where price exceeds their average costs, while others may face temporary losses. (Baxter and Hirst, 1995). 


\subsection{VALUATION IN A COMPETITIVE ENVIRONMENT}

According to Torries (1996), there are three general groups of users for evaluation projects. These consist of private investors, lenders, and governments. Valuation of electricity generation assets has a large potential user audience. These include Public Utility Commissions (PUC's), government tax and revenue agencies, investor's, potential buyers and sellers, and bankers. Each of these potential users may prefer one method of valuation to another depending on the goals of the user. PUC's may be interested in the cost approach methodology because of the necessity for a regulated industry to cover its costs. Government tax and revenue agencies are interested in the valuation of physical assets. Investor's, buyer's/seller's and bankers (lenders) will be interested in the income and the stock $\&$ debt approach due to expected returns to the investor.

An early court case involving valuation was Smyth v. Ames in 1923. Since then many court cases have attempted to seek ways to value utility assets. The Smyth v. Ames case introduced the "fair value" doctrine to define value. Most utilities previously utilized the reproduction-cost method. The decision in the Smyth v. Ames case is as follows concerning "fair value":

"We hold...that the basis of all calculations as the reasonableness of rates to be charged by a corporation...must be the fair value of the property being used by it for the convenience of the public. And, in order to ascertain that value, the original cost of construction, the amount expended in permanent improvements, the amount and market value of its bonds and stocks, the present as compared with the original cost of construction, the probable earning capacity of the property under particular rates prescribed by statue, and the sum required to meet operating expenses, are all matters for consideration, and are to be given such weight as may be just and right in each case. We do not say that there may not be other matters to be regarded in estimating the value of the property. What the company is entitled to ask is a fair return upon the value of that which it employs for the public convenience. On the other hand, what the public is entitled to demand is that no more be expected 
from it...than the services rendered... are reasonably worth. (Hayward and Schmidt, 1999, pg 16)."

\subsection{TYPES OF ELECTRICITY PROVIDERS AND RELATED TAX ISSUES}

According to Anderson (1999), electricity is provided by four types of organizations. Each of these organizations has been taxed differently in a regulatory environment. Investor owned utilities (IOU) serve approximately 77 percent of U.S. customers and are taxed as corporations. Publicly owned utilities provide electricity for 14 percent of U.S. customers. Publicly owned utilities are primarily municipal utilities which are part of state and local governments and are not subject to local or state taxes. Rural electric cooperatives are owned by the customer and provide electricity to 8 percent of U.S. customers. They do not pay federal and state income taxes but do pay other types of taxes. The federal government also operates 10 federal electric utilities including the Tennessee Valley Authority (TVA) and the Bonneville Power Administration. Federally owned utilities are exempt from federal, state, and local taxes. In a deregulated environment, IOU's will have to compete with these other types of utilities which typically pay little or no taxes.

The move from a regulated to a competitive environment will have an affect on state and local taxes paid by IOU's. In 1996, IOU's paid $\$ 13.865$ billion in state and local taxes nationwide. This comprises $60 \%$ of the taxes that go to state and local governments and constitutes approximately $8 \%$ of IOU's operating revenues. Compared to the $8 \%$ of operating revenue paid by IOU's, other utility companies pay only 2.7 percent of their operating revenue in state and local taxes. Due to deregulation and competition in the electricity generation industry, many utilities are appealing to state and local governments to lower their taxes to a level comparable to those paid by other industries. (Anderson, 1999). WV is currently studying the 
tax revenue issue in an effort to maintain tax revenue neutrality. This effort is aimed at maintaining revenue when taxes decline due to decreased gross receipts tax or lower plant valuations. Some states have instituted or are planning to institute a consumption tax at the distribution level to make up for any loss in tax revenue.

Depending on the state, a variety of taxes are levied on utilities. These taxes can include gross receipt taxes, kilowatt-hours taxes, capacity taxes, regulatory assessment fees and license taxes. Tax rate calculations vary considerably among states and result in large differences in the state and local tax burden of IOU's. One of the special taxes that are imposed on utilities is the gross receipts tax. This tax consists of a single or graduated rate applied to a utility's gross revenues. There are 19 states that currently levy this tax compared to 40 states in 1990. Many states will lose gross tax revenues with deregulation because most restructuring plans call for immediate rate reductions of $10 \%$ to $50 \%$ for in-state customers. If the demand for electricity is inelastic, this decrease in gross tax receipts will reduce state tax revenues. (Anderson, 1999) Property tax is one of the largest taxes imposed on electric utilities and comprises a significant portion of the taxes received by local governments. Thus, many public school districts are highly dependent on utility tax dollars resulting in concern for maintaining school funding in a deregulated environment if property tax laws change. Electric utility property taxes have historically been based on cost rather than FMV because it is (1) considered difficult to determine FMV of an electric power plant and (2) the utilities profit is based on costs in a regulated environment. Unit valuation has been the preferred method as opposed to individual power plant valuations. Tax assessors first determine the "unit value" of the entire utility based on the cost of the utility's taxable assets, income earned, and the value of the utility's securities. 
This unit value is divided among the various tax jurisdictions in which the utility operates. Many states utilize this method while other states assess electric utility property locally.

The classification of electric utility property as personal or real property also affects the rate at which property is taxed. The state of New York classifies property as taxable real property if owned by a regulated utility whereas the same property would be considered nontaxable personal property if owned by another entity. Eleven states tax property owned by an electric utility at a higher rate than identical property owned by a nonutility. In Mississippi, electric utility property is assessed at $30 \%$ of its market value, while other business property is assessed at $15 \%$ of market value. Since independent power producers are not considered to be utilities, they are not subject to higher tax rates. The amount of property taxes is likely to decrease under deregulation since the cost of most power plants is greater than their market value. (Deloitte and Touche, 1996).

Many utilities are asking for compensation for their stranded costs in the transition to deregulation. These stranded costs are estimates of the costs that a deregulated utility will not be able to cover if the competitive price for electricity is lower than the regulated price. Stranded costs across the country are estimated to range from $\$ 50$ billion to $\$ 300$ billion for all electric utilities. (Anderson, 1999). 


\section{Chapter 3}

\section{Literature Review}

\subsection{PROPERTY TAX REFORM}

In a competitive market with utility properties valued at fair market value most state and local governments would incur significant tax revenue reductions. According to a study by Deloitte and Touche (1996), competition in the electric utility industry will likely cause tax revenues to decline in many jurisdictions (based on the cost approach valuation method applied during regulation) due to lower electricity prices and a shift in market share from more heavily taxed to less heavily taxed providers. Taxes that have been passed through to electric utility customers will be borne, at least in part, by the utility itself and will affect who provides electricity and where it is generated. In order to facilitate the transition to a competitive market, Deloitte and Touche recommend:

-Replacing existing utility taxes with electricity consumption taxes.

-Reforming property taxes to remove the differential treatment of utility and nonutility property.

-Increasing the reliance on income taxes rather than gross receipts taxes. A recent report by the Federation of Tax Administrators (Deloitte and Touche, 1996) proposes that states shift to consumption-based energy tax. The study cites three advantages of this form of taxation:

- Tax revenues are not dependent on the price of electricity.

- No problems with nexus (Nexus is the minimum connection the taxing state must have with the corporation or the activity being taxed) exist if the tax is imposed on the distribution company.

- The distinction between whether the power is provided by a utility or independent generator would be irrelevant since the tax is on distribution. 
Electric utility deregulation presents a challenge for state legislatures as they attempt to introduce competition while maintaining a steady level of tax revenues. The existing framework of complex taxes that differ significantly among states makes the problem more difficult. An increased awareness of the differences between state tax structures and their resulting impact on utility tax burdens is necessary in order to develop a "level playing field" whereby all electric utilities face fairly equal state and local taxes. (Anderson, 1999)

\subsection{VALUATION METHODS FOR DEREGULATED ELECTRICITY GENERATORS}

In some states, taxable real property for utilities includes all immovable machinery or equipment. Notably, immovable machinery or equipment owned by other types of industries in the state is considered non-taxable personal property. Local governments are responsible for the determination of the value of taxable real property. Usually state law requires that local governments value generation facilities under the reproduction cost new less depreciation (RCNLD) approach because generation facilities are considered "specialty property". Under this method, the value of the property equals the reproduction cost minus incurable and curable physical depreciation, functional depreciation, and external depreciation. In comparison to other methods of real property valuation, Murray believes that the RCNLD method results in the maximum valuation of the property. This is not necessarily true when considering such variables as market power or intangible property. Establishing the maximum valuation for generation facilities may reduce the tax burden on other taxpayers in the locality but could affect a utilities costs and competitiveness. (Murray, undated) 
Many of the valuation approaches for utilities considered "specialty property" will no longer be valid once these utilities complete their transition to a competitive market. This is because criteria such as marketability (ability to be sold) will no longer categorize utilities as special property.

According to Murray (undated), there are two other valuation methods besides the RCNLD approach that a local assessor may apply: the income approach and the market approach. With the income approach, the property is valued based on the amount of net income the property is expected to produce. This approach would create fair and competitive tax burdens on utility generation facilities for two reasons. First, many utility generation facilities have excess generating capacity. If the income approach is applied, the taxable valuation of utility generation facilities will not include that portion of the facility consisting of capital assets used to produce income. This means that electricity rates will not include taxes on the cost of excess capacity. Secondly, valuation under the income approach will result in lower valuation than under the RCNLD approach. The income approach may result in a lower valuation and this may promote the goals of creating a competitive energy market by lowering electricity prices and placing utilities on a level playing field.

Under the market approach, an assessor establishes a value for the property by comparing the property being appraised to similar properties that have been recently sold. While this approach should also result in a lower valuation of utility generation facilities than the RCNLD approach, it will involve elements of comparison that are artificial given that no two properties are the same. (Murray, undated). If a fossil fuel steam plant's value is calculated by RCNLD, the appropriate replacement cost will likely be a gas-fired turbine generator. The cost of replacing generation capacity will depend on the most feasible technology. 
Compared to the technology oriented RCNLD approach, the price oriented income approach or the market approach may result in lower assessed values for electricity generation facilities depending on the technology used to provide the same generation capacity. This will be to the benefit of the electricity generation facility and the competitive environment. Without intervention by the electricity industry, it is contended that local assessors may continue their valuation assessments based on the methods used under a regulated environment such as the RCNLD method. According to Murray (undated), utilities should propose legislation to provide a form of central assessment, which would treat all generation facilities the same as other industries in the state. This kind of legislation may face strong lobbying against it because of the loss or the chance of loss of revenues by local governments.

Schneider (1999) addresses the different valuation methods citing that the rate base of a regulated utility will become irrelevant in a competitive market. The demise of rate regulation will cause some states using unit valuations to shift to valuations of individual plants. In order to determine FMV, many valuation issues will have to be resolved by the courts such as the influence of above-market power purchase contracts on plant value, recovery of stranded costs, and the continued legitimacy of the unit approach to value. Currently, West Virginia utilizes the unit value method and the income approach (West Virginia Public Service Commission Report, 1997). Schneider (1999), states that practitioners litigating power plant valuations must consider several strategies. In the replacement model, a power plant can be readily valued by comparing its performance characteristics to a new, state-of-the-art facility. That facility, in today's market, is the combined-cycle gas turbine power plant. In such plants, pollution abatement costs are generally lower than coal fired plants. 


\subsection{VALUATION ISSUES}

In James Bonbright's book, The Valuation of Property, he states that property can be valued in many different ways:

Not only in law, but in business, accountancy, commercial appraisal, and economics, "Value," in the language of Justice Brandeis. "is a word of many meanings."(pg.17)

According to Bonbright (1937), there are 89 definitions to describe value as it relates to property. The difficulty of arriving at the appropriate value for a property is often based on the reason for the valuation. Legal issues dating back to the early part of the century are repeated in the courts today due to the different concepts of value. Lower and higher courts continue to hear arguments concerning the appraised value of property as a property owner's definition of value may differ from the appraiser's valuation.

Examining the theories behind valuation is essential to understanding the valuation process. It is possible to arrive at many different appraised values. Bonbright (1937) states that, of the 89 varieties of value, four concepts are stressed as being fundamental to all. These include: market value, value to the owner, intrinsic value (in the sense of "justified selling price"), and normal value. Of these concepts, the first two are primary; the last two are called hypothetical market values. In Bonbright's (1937) words, "no fundamental definition of value is attempted other than the favorable importance of property, as distinct from all other characteristics (such as bigness, cost, color, utility, scarcity) which merely have a bearing on this importance" (pg.38). Furthermore, one must analyze the concept of value with relation to the purpose of each valuation, the techniques of appraisal adopted, and the nature of the property appraised. 
Each method of valuation should be critically appraised as to its advantages and limitations. Much of the confusion as to valuation methods is due to the fact that different concepts of value require different methods of valuation; "that the evidence of value, like value itself, is often expressed in monetary terms; and that there are many legal situations in which the evidence of value is superior to value itself as a standard for legal judgments." (Bonbright, 1937, pg.40).

Bonbright (1937) argues that actual sales prices are generally thought the most obvious measure of value. On theoretical grounds that method can be challenged if the market is not highly organized, the sale is not representative, the transaction is too distant in time or place, the property is essentially different, the transaction occurs in a different market (wholesale rather than retail), or different quantities are involved. Bonbright (1937) believes that the actual or original cost is a better measure of value to the owner than of market value. Actual or original cost measures market value only when it coincides with the replacement cost of the property in question. Contrary to popular belief, original cost is more often a matter of opinion or estimate than a precise fact derived from the accountant's books, particularly if the pertinent records are missing or the circumstances surrounding the acquisition of the specific property fail to reveal its true cost. A close approximation of original cost to present value may exist for utilities whose original cost is a "legally accepted factor in the determination of 'fair value' and may therefore have a bearing on the commercial value of the property, through its influence on rates and thereby on earnings" (Bonbright, 1937, pg. 146). Much consideration has been paid to replacement cost and the theories behind its relevance as a measure of value. According to economic theories of competitive prices, "that the value of commodities produced and marketed under conditions of competition tends to equal the production (or reproduction) costs", is 
rejected because of frequent discrepancies between market values and production costs. The justification for the use of replacement costs is found in the principle of substitution in that, "no given property can be worth more than the cost of acquiring equally desirable substitute property" (Bonbright 1937, pg. 175).

According to Bonbright (1937) there are two basic truisms that are often disregarded: that replacement costs can be accepted as evidence of value only for such properties as are worth replacing, and that replacement costs should normally be measured by the cost of an equally desirable substitute, the cost of identical replacement being relevant only in that rare situation where an identical property would be reconstructed.

Schneider (1999) states that practitioners litigating power plant valuations must consider several strategies. In the replacement model, a power plant can be readily valued by comparing its performance characteristics to a new, state-of-the-art facility such as the Combined Cycle Gas Turbine (CCGT) plant. In such plants, both pollution abatement and initial construction costs are generally lower than those of coal fired plants.

Power plant valuation litigation should also include a projection of market prices of electricity. Such projections are necessary for the income approach and for determining economic obsolescence under the cost approach. With deregulation, rate-base multiplied by a permitted rate of return can no longer be a reliable means for predicting income earned by an electric utility. With competition at the wholesale level, there now exist observable market prices for electricity. Theoretically (with competition) these prices should be below current utility prices and below prices guaranteed in PURPA ${ }^{\text {Q }}$ contracts. Although this is not the case in California, it theoretically should be, as competition will drive down prices because it will bring

PURPA is the Public Utilities Regulatory Policy Act that was passed in 1978. This act required utilities to purchase power from nonutility generators. 
about cost efficiencies. An appraiser may be able to determine a market area price projection by examining the average cost of production of the utilities in the market. In a competitive market, historical average costs will not set market prices, but rather, the marginal cost of production of the most efficient plant available to produce a given demand. Competitive plants will produce as long as their marginal cost of generating electricity is covered. Competition will force cost cutting and increased efficiency that will lower overall market costs. (Schneider, 1999)

With disaggregation and competition, sales of power plants are occurring frequently. In some states (California, Maine and Massachusetts), current laws favor utility divestiture of generation assets. Independent power producers are also consolidating on geographic or technology lines and consequently restructuring their portfolios. Using a comparable sales approach can be difficult as not all plants have similar property values. Power plant sales can include the transfer of power purchase agreements, expectations that a utility's customer base will follow, stranded cost recovery rights, environmental liabilities, other intangible contract rights, and other assets or costs not directly related to the tangible or taxable property. (Schneider, 1999).

Other issues of litigation involve intangibles, value-in-use, stranded cost recovery rights, and the demise of the unit. Two related issues can be litigated under either intangible property or the value-in-use concept depending on the law of a particular jurisdiction. These issues involve PURPA contracts and whether they can be used to value a plant, and whether a utility's stranded cost recovery rights can be used to value its generating plants. The issue is whether a PURPA facility contract and its income can be used to value the underlying plant. Arguments for and against using PURPA to determine FMV depend on jurisdiction. A taxpayer will argue that the contract is a separate asset with a separate value apart from the physical plant. Arguments 
against including the value will be strongest where intangible property (or business value) is not subject to property taxation and there is case law requiring real property to be valued through estimating current market rent and not through income from long-term leases. The taxing jurisdiction will argue that the PURPA contract and the physical plant cannot be separated because if it wasn't for PURPA the plant may not have been built or maintained its existence. A taxing jurisdiction will argue that franchises, permits and contracts be considered in valuing property. A current court case of a PURPA facility in Michigan involves a coal-fired plant. The taxpayer is relying on a replacement cost analysis and a projection of market prices of electricity to establish FMV. Intangible property is not taxable in Michigan and the state's statutes specify that market income rather than lease income must be used to value real property. (Schneider, 1999).

The cost approach considers the investment in current labor and materials required to assemble an independent power project possessing comparable utility to the subject property. Comparable utility implies that an asset generates similar economic satisfaction but does not necessarily require that an asset be an exact duplicate of the subject. An asset is perceived as being an equivalent asset if it possesses comparable utility. To employ the cost approach, expenditures for equipment such as turbines, generators, boilers, fuel-handling equipment, ashhandling equipment, cooling towers, and additional items such as engineering, financing, fees, permits, legal, and other indirect costs must be determined. The individual component costs are then added to estimate the original facility-construction cost. (Ellsworth, 1994).

The income method approach assumes that property is worth the present value of the income stream it can generate. Under traditional regulation, utilities project future income based on the rate of return on the rate base discounted by the market cost of capital. If the market cost 
of capital approximates the allowed (and assumed achieved) rate of return, the income indicator will approximate the rate base. Under deregulation, an appraiser must estimate the prospective income that a utility's generating plant is expected to earn based on a reasonable projection of electricity market prices and how they will affect the plants dispatch. Operating costs, such as fuel prices, also are projected and discounted to present value. To make these projections, an appraiser can commission studies from energy and economic forecasting firms specifically for the plant at issue or use reports from the Energy Information Administration or the Gas Research Institute, which provide a more global perspective. The utility can also use price projections that it has used to conduct studies of stranded cost recovery.

These studies typically provide the portion of net book cost the utility would likely not recover, and by extension, what an investor likely would not purchase. If the assessment is based on net book value, such studies will prove useful to benchmark property values. Depending upon the quality of the study, it may be combined with competent appraisal evidence and used to prove a value reduction in court. A truncated projection is also possible with an income based on a rate base multiplied by permitted rate of return for several years, converting to a market-price income projection for those portions of the load that will be sold in competitive markets. If the plant is already producing primarily for a wholesale market then competitive prices could be projected. State law should be examined to determine if using an income stream based on rate base or including stranded cost recovery allowances would improperly set the value of the property based on the owner's use rather than its fair market value or by valuing intangible assets. Fair market value is based on hypothetical buyers and sellers in the marketplace. If the only buyers would be independent power producers, their purchase price would be based only on the value of the tangible assets. Only the utility (not an independent 
power producer) would have the ability to collect both the income from rate base or stranded costs. Under most state laws, prices from above-market power purchase agreements should not be used to project income, since doing so will value the non-taxable intangible contract rights rather than the tangible property comprising the power plant. (Schneider, 1998).

Blacconiere, Johnson, and Johnson (1999), predict that deregulation can decrease the importance of book value and possibly increase the importance of earnings. This study was conducted by examining changes during a 1988-1996 time period for a sample of large investor owned utilities. The time frame in the study covers firms during and after deregulation. The study's hypothesis is that the trend toward deregulation triggered by the 1992 Act is associated with changes in the market's use of accounting information.

According to theory (Blacconiere, Johnson, and Johnson, 1999), if all costs are eventually recoverable and the allowed return on investment is equal to the cost of equity capital, the market value of equity for an electric utility should be approximately equal to book value under regulation. Assuming that there is little uncertainty about the allowed return and little measurement error in book value, earnings are expected to explain little variation in market value incremental to that explained by book value. In contrast, in a competitive environment where utilities are not assured a return on book value, earnings signal a firm's ability to generate future abnormal earnings and should have greater importance. Based on this study, the authors predict that book value will become a less important determinant of market value following deregulation. 


\subsection{STATE TAXATION ISSUES}

Few deregulating states have studied the issue of the effect on property tax revenue from deregulation as has Ohio. Historically the tax treatment of public utilities was not an issue. In the case of Ohio, public utilities were monopolies that were allowed to earn consistent rates of return and were taxed heavily. Utilities did not have to compete for customers (i.e., rate payers) and could easily pass all taxes through to their ratepayers in the form of higher rates. The utility industry was an effectively regulated monopoly. The state, therefore, collected monopoly rents through taxation.

In Ohio electricity is supplied by 8 IOUs, 80 municipal utilities, and 30 rural electric cooperatives. The investor-owned utilities have guaranteed territories and so face little competition except from the municipal utilities. Ohio Power [part of the American Electric Power (AEP) system], which serves the southeastern region of the state, relies heavily on coalfired generators and has among the lowest rates in the nation; Cleveland Electric and Toledo Edison rely heavily on nuclear power and have rates that are among the most expensive. The high rates stem from the high cost of the nuclear power plants and the rate-of-return-based rates, which are set to recover their cost over a period of 40years. Toledo Edison ranks $6^{\text {th }}$ among all IOUs in the country in terms of percentage of plant-in-service tied up in stranded nuclear assets.

Advances in technology are providing ever more opportunities for competition in industries that were once thought to be irretrievably monopolistic. Traditional distinctions between the industries are becoming blurred. In this context, the rationale for the separate tax treatment of utilities and other businesses is vanishing. Continuing to pursue such policies will result in larger and larger distortions in economic decision-making. Experience with $\mathrm{MCI}$, a telephone service provider, has shown that differential tax-treatment with competitors in the 
same industry cannot be maintained in the long run. With or without a policy change, the impact of public-utility restructuring on local revenues is expected to be particularly problematic since public utility specific taxes account for $8 \%$ of all local revenues and $14 \%$ of local revenues to school districts even though they account for only 5.3\% of state Gross Receipts Fund revenue. For the purpose of the property tax, Ohio assesses general business tangible property at $25 \%$. In Ohio many industries classified as public utilities are assessed greatly in excess of that. A natural gas company, for example, would pay over three times as much tax as a non-public utility (such as an energy broker would pay on the exact same property). This treatment is jeopardizing the ability of Ohio's utilities to compete and may prevent Ohio from reaping many of the benefits of the new competitive environment. (Mahaffey, undated)

The public utility property tax is, however, an important source of revenue for local governments, particularly schools. In 1995, Ohio public utilities paid \$1,026.6 million in property taxes to local governments of which $\$ 718.7$ million went to schools. This was the equivalent of $32 \%$ of the state basic aid paid to school districts over the same time period. Ohio's electric utilities contributed the largest share of taxes with electric utility property accounting for $55.8 \%$ of total assessed value. The property of telephone and telecommunication companies accounted for the next largest share (24.7\%) followed by the property of natural gas companies (10.9\%) and pipelines (4.9\%). The remainder (the property of railroad companies, rural electric co-ops, waterworks, etc.) accounted for 3.7\%. Local dependence on public utility property tax revenue varies greatly throughout the state. Although the property of utilities is apportioned among all the taxing districts in which the utility operates (by wire miles in the case of telephone companies, for example), inevitably certain districts such as those with a large electric generating plant, a substation, or a concentration of heavy electrical users receive a much 
larger share of the utility's valuation along with a much larger share of its property taxes. (Mahaffey, undated))

The federal government has jurisdiction over interstate services, interstate pipelines, and interstate electric transmission. The state has authority over local services such as local exchange companies, local distribution companies, and retail electric service. However, changes at the federal level have consequences at the state level for both regulatory and tax matters. Although the consequences vary somewhat by industry, many of the issues recur. Therefore, lessons learned from the restructuring of the telecommunications industry may be useful in anticipating the issues, problems, and solutions likely to result in the restructuring of electric utilities. (Mahaffey, undated))

A major problem with electric power restructuring is that there has been significant "over capacity" in the industry especially in the larger overvalued coal-fired and nuclear generating plants. Newer plants are typically smaller, often operated by non-utilities, with operating costs much lower than the large coal-fired or nuclear plants. These newer plants are usually based on natural gas turbine technology. Initial construction costs are lower and historically natural gas electricity generation has experienced lower costs than traditional fuels such as oil or coal. As competition unfolds in the industry, many of these larger plants may turn out to be uneconomical to operate in the new environment, leading to the existence of a lot of "stranded investment" in the industry. The stranded investment problem is one of the major stumbling blocks in the movement toward competition in the electric industry in the U.S. Estimates of potentially stranded assets in the electric industry in the U.S. range from $\$ 100$ billion to $\$ 135$ billion. Stranded nuclear assets alone account for approximately 70 percent of the U.S. total. Ohio ranks 6th among all states in terms of stranded assets. Each of the states in the top ten have stranded 
nuclear assets in excess of $\$ 3$ billion. While FERC rule 888 called for full recovery of stranded assets incurred before June 11, 1994, its jurisdiction is limited to interstate matters, i.e., the wholesale market and the transmission system. Well over 90 percent of strandable assets are located at the generation level, which falls under state jurisdiction. Regardless of how states decide to handle stranded costs, decisions to close plants will be based on marginal and variable costs, not the sunk costs of the value of stranded capital assets.

The District of Columbia, like most state and local governments, has taxed its utilities more heavily than other industries. Deregulation of the utility industries therefore presents significant tax revenue issues for the District, including highly political concerns about a possibly uneven playing field where utilities and their nonutility competitors would face different tax burdens. As deregulation proceeds, several tax policy challenges in the electricity industry must be met. These include:

- maintaining an even playing field in taxation policy within and between industries affected by deregulation;

- offsetting lower tax revenues resulting from lower energy prices, which restructuring is expected to facilitate;

- addressing increased tax collection administration costs that might emerge in the utility industries as many suppliers of natural gas and electricity are allowed to enter the local market; and

- counteracting or compensating for possible reductions in the energy industries' commitment to social programs due to competitive pressures.

(Coopers and Lybrand, 1997).

The optimum size of power plant has decreased greatly over the past 15 years from plants in excess of 500-megawatt capacity to plants in the 50 to 150 megawatt range. The smaller gas- 
fired turbine plants can be put into operation within a year of initial investment compared to the 10 years on average it takes to bring the larger fossil fuel or nuclear plants on line. The cost of operating these new plants is much smaller so that the variable cost of bringing on additional plants at the new technology is less than the variable cost of operating most plants constructed in previous decades. For example, it costs 3 to 5 cents per kilowatt hour ( $\mathrm{kWh}$ ) to operate the smaller gas-fired combined-cycle generating facility compared to the 4 to 7 cents per $\mathrm{kWh}$ for coal-fired plants and the 9 to 15 cents per kWh for nuclear power plants. (Mahaffey, undated)

The more expensive utilities are the ones that face the greatest competition from the municipals. Since the municipals buy electric power in the wholesale market, they can purchase power from lower cost utilities or generators, which may be located in a different service territory, a different state, or even a different country. The municipals are also exempt from the property tax. Competition occurs as either municipalities annex territories and extend their services to these new territories or as new municipal utilities are formed to provide large industrial users in their jurisdiction with lower-priced energy. As industrial users leave (or threaten to leave) the IOU's service for the cheaper power, IOUs may in turn offer them lower rates. These rates are known as "economic development" rates. The shareholders and remaining customers of the utility are left to make up the difference. The advent of competition and retail wheeling is expected to expand this type of pressure to reduce rates and shift burdens statewide among utilities in general, not just between municipal utilities and IOUs. Although taxes are not the sole cause of the differences in rates among IOUs, they do contribute to the problem. Property taxes and required rates to recoup taxes increase as the value of a utility's property increases. 
While the high cost of the nuclear power plants have been a major aggravation to utility consumers in northern Ohio, they have been a boon to schools in the area that receive a large share of their funds from property taxes on the plants. Most notable are Benton Carroll Salem Local School District in Ottawa County (site of the Davis Besse nuclear power plant) and Perry in Lake County (site of the Perry nuclear power plant). In 1995 both received $62 \%$ of their total property tax revenue from taxes on electric utility tangible property.

For the purposes of public utility property taxation, the production or generating equipment of electric power plants is assessed at $100 \%$ of true value, and the non-generating equipment is assessed at $88 \%$ of true value. True value is defined as $50 \%$ of original cost, where original cost equals book value minus the allowance for funds used during construction. While not included in the property tax base, original cost is included in a firm's rate base, where it is considered a "regulatory asset." In some cases it may become a stranded regulatory asset. For the most part, $70 \%$ of the tax revenues derived from generating plants are allocated to the taxing district where the plant is "sitused;" while the remainder, along with the non-generating plant, is apportioned throughout the utility's territory in accordance with the value of the firm's transmission and distribution system. However, in the case of a utility valued in excess of one billion dollars, any valuation in excess of $\$ 420$ million is apportioned like the nongeneration property. This provision affects the apportionment of property associated with the Perry nuclear power plant and the Zimmer coal-fired power plant in Clermont County. Nevertheless, school districts, which host an electric power plant, receive a disproportionate share of the public utility property tax. (Mahaffey, undated). Levin and Driscoll (1996) note that $40 \%$ of the electric utility tangible property value is located in the 35 school districts (out of a total 611) which have power plants. The districts containing the largest amount of utility property valuation are Perry and the 
New Richmond Exempted Village School District. The erosion of electric utility property tax revenues in Ohio is likely to come from two main sources:

- existing utilities writing down their overvalued assets, and

- the disincentives for non-utilities (and ultimately utilities) to locate new plants in Ohio.

In comparing the property tax per kilowatt-hour incurred by Ohio electric utilities with that incurred by utilities in the surrounding states, only Michigan has a comparable property tax burden on electric utilities. However, this observation would now be somewhat misleading. Unlike Ohio, utility property in Michigan was (and is) treated like industrial property for taxation purposes. The high tax burden in Michigan simply reflects a relatively high property tax burden on business property in general. Moreover, since 1995, taxes on business property in Michigan have been reduced by about $20 \%$. For the purposes of property taxation, non-utility generators are treated like utilities. In other words, the "exempt" in exempt wholesale generators just means that the firm is exempt from the Public Utility Holding Company Act (PUHCA); it is not exempt from Ohio's public utility property tax. (Mahaffey, undated).

The Ohio Revised Code, defines for the purposes of public utility property taxation, an electric company as "Any person... when engaged in the business of generating, transmitting, or distributing electricity within this state for use by others...” This provision results in a significant tax disadvantage for non-utility generators in Ohio compared to their situation in other states. Such entities would typically be assessed for taxation at $100 \%$ of true value. However, since they are not regulated public utilities, they cannot be assured of recovering the higher tax assessments in rates. Consequently, it makes little sense for them to locate such facilities in Ohio particularly when the property tax burden is generally much lower in the surrounding states. 
(Moreover, if competition means that generators belonging to IOUs can no longer be assured of recovering the higher taxes in their rates, then IOUs will not locate future investment here, either.) Given the unfavorable climate, it is not surprising that in 1991 non-utility generators in Ohio provided less than $2 \%$ of the state's total electricity generation. In comparison, non-utility generators account for over 10\% of electricity generation in Pennsylvania and Michigan. Ohio is not only losing property tax revenues as utilities write down the assets of the older electric power plants; it is also not gaining revenues from the newer facilities that are being built. (Mahaffey, undated).

In either case, local governments in Ohio stand to lose revenue. This has already begun to happen in certain Ohio school districts that depend heavily on the revenues from nuclear power plants. Public utility property values fell by $2.7 \%$ in Perry school district in $1992-93$ and by $0.6 \%$ in 1993-94. This erosion can only be expected to continue and spread to districts dependent on large electric generating facilities however powered as the process of electric utility restructuring continues and utilities position themselves to survive. (Mahaffey, undated).

Doing nothing about the public utility property tax is not a long-term option for states like Ohio. In one scenario such a policy would result in a continuing erosion of the tax base as assets are taken out of service or written down and their generating capacity replaced by facilities located in other states. Adjacent states would generally benefit from investments in generating capacity that would otherwise have taken place in Ohio. Alternatively, a disgruntled utility might launch another legal challenge in either state or federal court arguing that it was denied equal protection due to differential tax treatment. Losing such a challenge could prove quite costly to both local governments and the state. 
Calculations based on Ohio State Tax Department data detailing the assessed value of public utility personal property were developed by type of utility. The Ohio Legislative Budget Office also used the Tax Department's estimate that $47 \%$ of electric utility property in 1995 was generating plant (i.e., valued at $100 \%$ of true value). An effective tax rate on all public utility property of 67.83 million was calculated based on the assessed values and total public utility property tax revenue for 1995 . The revenue loss presented in table 1 is based on the tax rate being reduced to $25 \%$. True value estimates for each class of utilities were found by dividing the assessed value by the appropriate assessment rate (which was $93 \%$ for electric utilities). The true value multiplied by an assessment rate of $25 \%$ times the 67.83 million is contained in table 1 .

Table 3.1. Tax revenue loss from Ohio utilities

\begin{tabular}{|lc|}
\hline \multicolumn{2}{|c|}{$\begin{array}{c}\text { Cost of Reducing Assessment Rate } \\
\text { on Public Utility Property by Class } \\
\text { (Revenue loss) }\end{array}$} \\
\hline \multicolumn{2}{|c|}{$\begin{array}{l}\text { Natural Gas } \\
\text { Pipeline }\end{array}$} \\
Electric Power & $\$ 77.3$ \\
Other public utility property & $\$ 402.6$ \\
Total & $\$ 11.6$ \\
*Values are in millions of dollars/year. & \\
\hline
\end{tabular}

Source: Mahaffey, undated. 
Table 3.2. Ohio utility tax burden

\begin{tabular}{|ll|}
\hline \multicolumn{2}{|c|}{$\begin{array}{l}\text { Property Tax Burden Comparison } \\
\text { Property Tax per Retail kWh (Cents) }\end{array}$} \\
\hline Ohio & .66 \\
& Cleveland Electric \\
Toledo Edison & .59 \\
Ohio Edison & .50 \\
Cincinnati Gas \& Electric & .47 \\
Columbus Southern Power & .40 \\
Dayton Power \& Light & .37 \\
Ohio Power & .24 \\
Michigan & .44 \\
Detroit Edison & .33 \\
Consumers Power & .14 \\
Indiana & \\
Indiana Power & .19 \\
Pennsylvania & 17 \\
Pennsylvania Electric \\
Pennsylvania Power . \\
West Virginia \\
Appalachian Power \\
Wheeling Power \\
Kentucky \\
Kentucky Power \\
Kentucky Utilities \\
$\quad .03$ \\
\end{tabular}

Source: Mahaffey, undated.

Consequently, restructuring of the electric power industry is not likely to result in a hemorrhaging of property tax revenues as in the case of deregulated industries like natural gas. The drawback is that the law is likely to hamper growth and could ultimately increase the likelihood of bankruptcy for Ohio utilities. 


\subsection{CONSUMPTION TAX}

The Tax Focus Group from the state of Georgia has concluded that Georgia's present system of taxing electric utilities would be counterproductive to an open, competitive electricity market (PSC Georgia, 1997). The Tax Focus Group has proposed several plausible changes based upon modifications to the state and local tax laws. As a minimum the criteria for these changes should focus on allocative efficiency, horizontal equity, vertical equity, revenue adequacy and stability, economic growth and development, and administrative ease. Allocative efficiency means that tax revenues are raised without unduly affecting the patterns of production and consumption that would occur in the absence of taxation. Horizontal equity means that equivalent businesses should be treated the same. Disparate tax treatments of electricity providers would violate both of these principles. The Tax Focus Group has proposed several tax methods to meet these criteria but notes that they are worth further study. These include a tax on imported electricity, energy sales and use tax (excise tax) on the supplier, and an energy consumption tax on the consumer. (PSC, Georgia, 1997).

The tax on imported electricity and the energy sales and use tax would not necessarily effect property valuation or property taxes whereas the consumption tax could be used to replace lost municipal revenue and property taxes by imposing a tax on consumers of electricity, gas, and other forms of energy. Enactment could be coupled with the simultaneous elimination of one or more of (i) the sales/use tax on generating fuels, (ii) franchise fees, (iii) property taxes on utilities, and (iv) any tax(es) on gas that may cause problems given the restructuring of that industry. The consumption tax rate could be set at a level expected to produce the same amount of revenues as those being lost through the elimination of these other taxes. The tax could be based on volume such as kilowatt hours of electricity or on price. The law could provide for a 
true-up mechanism designed to adjust the rate periodically to ensure revenue neutrality. (PSC, Georgia, 1997).

\subsection{RISK}

There is increased risk associated with the introduction of competition into the generation of electricity. In a regulated environment fluctuations in demand and random equipment failure were dealt with by carrying excess capacity and redundant backup capacity. With competition private producers of electricity will seek to earn profits. Operations will be regulated by market competition that will govern prices and rates of return. As a result producers will monitor costs more closely at all margins and offer electricity at prices determined by marginal costs Because the cost of generating electricity will vary by reliability of service and whether demand falls on a peak or off-peak period, it can be expected that a more elaborate pricing system will emerge under competitive conditions. Competitive generation produces at least two additional sources of risk: a more complex pricing structure and loop flow problems when independent producers put electricity into the transmission network. Industrial customers, residential customers, distribution companies and transmission services will determine competitive pricing of electricity. Industrial customers can purchase electricity from regional distributors or directly from generators via bulk wheeling. The prices will be negotiable and subject to long-term contract. Residential customers may be in a position to contract for the most desired type of service and price. Distributors will be the most important shoppers for electricity in the system. Distribution companies will likely purchase their base and expected peak-loads by long-term contract with shortfalls and emergency requirements met in the spot market. In Florida, Energy Brokers operate a wholesale spot market for electricity and post prices hourly. In the 
transmission sector, long-term contracts setting forth transmission rights for each generator and fees for transmission services will have to be established. Fees might include an access charge covering capital costs and a fee set equal to the marginal cost of providing service. Because the latter includes maintenance and congestion costs, fees would vary with the volume and distance power is transferred. (Moorhouse, 1995).

Electricity generators will face the risk of uncertain prices for electricity due to the competitive market. The futures market for electricity is really a market for future generating capacity. The generator is said to be "long on capacity"; therefore, the firm will hedge by selling future contracts for the amounts and periods corresponding to its desired sales profile. (Shogren and Crocker, 1999)

The electric power industry is currently characterized by excess capacity in electric power generation. At the same time, improvements in the transmission system make it easier to rely on more distant energy sources. Assets valued in excess of the market price will not survive in a competitive environment. Either the facilities will be retired from service or their values will have to be written down. 


\section{Chapter 4}

\section{Theory}

\subsection{AD VALOREM TAXATION}

An ad valorem tax is based on the principle that the amount of tax paid should depend on the value of the property owned. Property tax is a major source of government revenue in the United States and is the major source of revenue for financing local government services including schools. In particular, the property taxes paid by electric generating facilities have been a major source of public school funding. With deregulation, the value of electric generating facilities may be determined by the valuation methods normally used for commercial/industrial property rather than by the cost approach used under regulation.

According to the Property Appraisal and Assessment Administration (Eckert,1990) real property appraisal is applied economic analysis. Basic economic principles are important to property appraisal as they apply to value, price, supply and demand, markets, equilibrium, anticipation, substitution, model specification, and model calibration. There are six basic rights associated with the private ownership of property: (1) the right to use, (2) the right to sell, (3) the right to lease or rent, (4) the right to enter or leave (real property), (5) the right to give away, and (6) the right to refuse to do any of these. These rights are known as the bundle of rights, which is the ownership of all the legal rights obtained with fee simple title. (Eckert, 1990).

The first step in the economic analysis of property appraisal is a broad study of the workings of the regional and local economy as relates to the parcel being assessed. The result is an understanding of the highest and best use of the land, i.e., the most profitable use at a specific time given legal, physical, and financial limitations. Highest and best use of the land/property is 
similar to general equilibrium analysis in economic theory. Equilibrium analysis determines how consumer preferences are translated through the price system into demand for goods and services and then to demand for the factors of production. (Eckert, 1990). This is important if the value of the plant depends on the market price of electricity.

The second step in economic analysis is the study of supply and demand for the identified highest and best use. The purpose of such an analysis is to develop a model that represents the behavior at a particular time of the supply and demand factors in the market being analyzed. Appraisers often use models for property that they value. All appraisal models either directly or indirectly estimate the present value of the future benefits of property. In this sense, models represent the workings of an efficient market. A model can also be a statement, formula or an equation. "The value of a property with a new building is the sum of the land value and the improvement value." (Eckert, 1990, pg 24) This statement is a model that expresses one approach to valuation, the cost approach. Expressed as an equation, this model becomes

$$
\mathrm{V}=\mathrm{LV}+\mathrm{IV}
$$

Where;

$\mathrm{V}$ is the estimated value of the property with a new building, $\mathrm{LV}$ is the value of the land and,

IV is the improvement value.

The formal development of a model in a statement or equation is called model specification. The model statement above for a cost approach is only adequate for new improvements and represents the supply side of the market. A valuation model for improvements in general would need a depreciation term:

$$
\mathrm{V}=\mathrm{LV}+(\mathrm{IV}-\mathrm{D})
$$

Where; 
$\mathrm{D}$ is depreciation.

A simple model for another approach to value is the income approach:

$$
\mathrm{V}=\mathrm{I} / \mathrm{R}
$$

Where;

I is the income it produces and,

$\mathrm{R}$ is a capitalization rate.

Historically, there have been three approaches to specifying valuation models that represent the market. The cost and income approach have been mentioned above. The third is the sales comparison approach. The model statement is, "The market value of a subject property is equal to the sale price of a comparable property plus adjustments to the sale price for differences between the attributes of the comparable and subject properties". Expressed as an equation,

$$
\mathrm{MV}=\mathrm{S}_{\mathrm{c}}+\mathrm{ADJ}_{\mathrm{c}}
$$

Where;

MV is the estimated market value of the subject property, $\mathrm{S}_{\mathrm{c}}$ is the sale price of a comparable property, and

$\mathrm{ADJ}_{\mathrm{c}}$ is the total dollar amount of adjustments to the sale price of the comparable property.

Appraisers normally use three to five comparable properties to estimate the market value of a subject property. (Eckert, 1990)

\subsection{LOCATION THEORY}

Location is a fundamental economic aspect important to the valuation of electricity generation assets. The location of a generation facility relative to a transmission grid and the 
location of other facilities is an important consideration of value. Other aspects of location include access to fuel sources and transportation such as roads, rivers, and rail.

The father of location theorists, von Thunen, (Isard, 1949), developed his theory based on Hicksian general equilibrium theory. General equilibrium analysis is a very special case of a general theory of location and space-economy which concerns itself with the local distribution of factors and resources as well as with local variations in price, and thus with the immobilities and spatial inelasticities of factors and goods. According to Englander (Isard, 1949), any entrepreneur, in choosing a location at which to produce or render a service, considers not only the supply prices of local inputs but also the ability to transport goods for consumption. A pattern of local price differences and the location of economic activities are simultaneously determined by a general theory of "local conditionality". As an example, the inability to erect new intrastate and interstate transmission lines makes existing access more valuable to potential buyers of generation facilities

\subsection{MARKET POWER}

Market power must be addressed in two broad categories (Shepherd, 1997). One is horizontal market power, which refers to the ability of a dominant firm (or firms) to control production and manipulate prices. The other is vertical market power, which is the ability of an existing firm to erect barriers to entry or otherwise shift costs and revenues among affiliates in ways that distort efficient market operation.

According to Shepherd (1997), in deregulated markets, market power could result in increased prices, reduced levels of electric output and employment, retarded innovation in electricity generation and transmission, cost shifting among buyers in different jurisdictions, and 
suppression of technological advances. As a result, the potential for market power could pose a serious threat to the successful restructuring of the electric industry.

A report by Edison Electric Institute (EEI, 1999) delves into the issue of market power and forced divestiture in a competitive market. An issue raised in this report is that electricity competitors are concerned that existing utilities can exercise market power in electricity markets. Market power exists when one competitor has the ability to deny, or unfairly restrict, access to consumers by other competitors and raise prices for a sustained period of time without losing market share. One issue concerning valuation is whether or not market power should be considered an intangible asset (goodwill) or an integral part of the value of a utility asset. This s important in identifying those intangible assets related to a plants' value.

Some potential competitors complain that utilities have horizontal market power because they own substantial amounts of generating capacity in an area. This belief ignores the large and growing number of electricity suppliers in wholesale markets around the U.S., many of whom own generation and will be competing head-to-head to provide electricity and other services to consumers. These suppliers include more than 4,000 non-utility generation projects that currently sell their power to utilities. The Federal Energy Regulatory Commission (FERC) examined the issue of market power in generation with FERC Order 888 and determined that no such power exists with respect to new generation. The order supported an earlier determination that entry into markets for new generating facilities is easy and competitive

Traditionally, estimation and prediction of market power has relied mainly on concentration measures. Concentration measures rely on historical data such as energy sales and transmission congestion. These measures are questionable since the incentive of many firms will change significantly after restructuring. Due to the weakness of analyzing market power based 
on concentration measures; the Federal Energy Regulatory Commission (FERC) has proposed using production-cost simulation modeling. According to Borenstein, Bushnell, and Knittel (1999), this procedure is flawed because modeling approaches simulate markets as if they were perfectly competitive and then apply measures of the potential for exercise of market power, such as concentration indices. This flaw results from the fact that a firm or set of firms, through the very act of exercising market power, will usually alter their production patterns in ways that violate the assumption of market-wide least cost production. Researchers are now employing more sophisticated market analyses in an attempt to capture the more strategic aspects of competition in the electricity industry (Borenstein, Bushnell, and Knittel, 1999). Although far from being perfect, these methods offer insight, both theoretically and empirically, into restructured electricity markets and thus offer significant advantages over the more traditional concentration measures. One central insight of restructured electricity markets is that a single market can at times, exhibit very little market power, while at other times, suffer a great deal from the effects of market power. The difference occurs when demand rises to the point that few producers have the capacity available to compete for the marginal load. According to Borenstein, Bushnell, and Knittel (1999), this difference is more apparent in the electricity industry due to the relatively limited production capacities of small producers, the widespread potential for transmission congestion, and the fact that electricity is expensive to store. These factors combine to make the elasticity of demand for electricity a crucial factor in determining the potential impacts of market power. The more traditional concentration measures do not provide information about the elasticity of demand and supply.

According to Hayward \& Schmidt (1999), market power "is coming to the forefront as a possible 'deal buster' to open access and competition" (Hayward \& Schmidt, 1999, Pg. 83). 
This is especially true of electricity generation or generation that must operate during transmission constraints. These suppliers are often referred to as "price makers" instead of "price takers". Price takers are usually in a highly competitive market and will take whatever price the market is setting. Price makers have control over the market, such as a monopolist, to set prices for their own gains. These prices are usually higher than the competitive price.

There are a number of factors (beyond the number and size of firms in the market) that impact the degree of competition with an industry. These factors include (Borenstein, Bushnell, and Knittel, 1999):

- The incentives of producers: In the near term, it is likely that electricity markets will feature a diverse set of firms, including publicly owned utilities, unregulated generation companies, and traditional vertically integrated utilities. Each type of firm is likely to respond differently to a given competitive environment.

- The price responsiveness (elasticity) of demand: In markets where customers can easily choose not to consume a product, or to consume a substitute instead, producers cannot raise prices far above costs without significantly reducing sales. Conversely, a producer that knows that its product is absolutely needed can profitably raise prices to very high levels.

- The potential for expansion of output by competitors and potential competitors: Just as a producer with very price responsive customers cannot exercise much market power, neither can a producer faced with many non-price-responsive customers. Transmission capacity into a region and available competition generation capacity are the main factors in determining the potential for short-run competitive entry or output expansion.

The fundamental measure of the exercise of market power is the price-cost margin which measures the degree to which prices exceed marginal costs. The price-cost margin is defined as:

$$
\frac{\mathrm{P}-\mathrm{MC}}{\mathrm{P}}
$$


Prices above marginal cost lead to both inefficient allocations since consumption will be too low in response to prices that are too high and to inequitable transfers from consumers to producers. (Borenstein, Bushnell, and Knittel, 1999).

\subsection{INTANGIBLE ASSETS}

Few intangible assets are included in an electric utility's rate base. Goodwill is an intangible asset that has not been accepted for purposes of ratemaking primarily because customers did not have alternative sources of supply. "Because the value of goodwill depends on an electric utility's earnings, to include it in rate base would result in circular reasoning" (Hayward \& Schmidt, 1999, pg.112). Normally, the burden of proof is on the electric utility to show tangible benefits to ratepayers for including goodwill in an electric utility's rate base. Under retail competition, this policy will change. (Hayward and Schmidt, 1999).

Goodwill is also referred to as "going concern". The going concern assumption is that a company will continue in operation for the foreseeable future. Charles F. Phillips, Jr., in his text The Regulation of Public Utilities: Theory and Practice, notes, "no cost measure of this value has ever been devised, making it 'purely hypothetical' and the 'most intangible of all the intangibles'". In two U.S. Supreme Court cases since 1933, the Court could not find a basis for a separate going concern value. On the other hand, one expert has found that "if enterprise has 'demonstrated a capacity for profitable operations under reasonable rates' it may be entitled to consideration of reproduction-cost-new less depreciation, including an intangible 'going concern value', under certain circumstances.” (Hayward and Schmidt, 1999).

A franchise is another intangible asset. For IOU's, franchises are contracts with industrial users, PURPA co-generators, or any other contract for power purchases. Including a value for an 
electric utility's franchise in rate base would require customers to pay a permanent return on monopoly privilege that they have granted to the electric utility. The rights and obligations of holders of franchises historically have not been controversial issues. This issue was debated in New Hampshire. The Public Service Company of New Hampshire (PSNH) believed it had an exclusive franchise to provide service within the state. The New Hampshire Public Utilities Commission decided that the company did not have an exclusive franchise. This left an opportunity for Freedom Electric Company (now Freedom Energy Company) to compete for PSNH industrial customers. (Hayward and Schmidt, 1999).

In his valuation study of the stock market's R\&D Investment during the 1980's, Hall (1993) utilizes Tobin's $q$ theory to value the intangibles regarding R\&D investment. This study is based on Tobin's $q$ theory, "in which the long-run equilibrium market value of the bundle of assets which compose a firm is equal to the book value of those assets, properly measured" (Hall, 1993, p259). Deviations from this relationship can either imply that the market is in disequilibrium and that firms have an incentive to undertake additional investment or disinvestments or that there is an unmeasured source of rents driving a wedge between the market and book value of the assets. Other researchers have studied the $q$ relationship to determine the value of intangible corporate assets or sources of rents, either observable or unobservable. (Hall, 1993).

Hall's valuation equation for corporate assets is derived in the following way:

"...a firm is viewed as solving the dynamic programming problem of choosing an investment strategy to maximize the expected present value of cash flow given a portfolio of stocks of capital assets. Because the assets cannot be adjusted costlessly, the present position of the firm in asset space matters in determining the value of the optimal program conditional on the assets. This implies that the value of the firm as an ongoing enterprise in any given period can be expressed as a function of the various stocks of capital. The value function of the firm is written as a sum of the composite capital $A$ and the intangible stocks 
$K_{1}, K_{2}, \ldots$ that are valued by the market but are not in the measured capital of the firm:" (Hall, 1993, pg. 262)

$$
V(A, \ldots, K 1, K 2, \ldots)=Q\left(A+\ldots+\gamma_{1} K_{1}+\gamma_{2} K_{2}+\ldots\right)^{\sigma} .
$$

To derive the estimating equation, introduce a multiplicative disturbance term, and take logarithms of both sides. This gives an equation of the following form:

$$
\log V=\log Q+\sigma\left(\log A+\ldots+\gamma_{1}\left(K_{1} / A\right)+\gamma_{2}\left(K_{2} / A\right)+\ldots\right)+e .
$$

The $\sigma$ coefficient describes the overall scale effect and should be equal to 1 under constant returns to scale of the value function (and no measurement error in $\log A$ ). The parameter multiplying the left-out stocks $\mathrm{K}_{\mathrm{i}}$ is the shadow value of those stocks relative to the value of $A$ (Hall, 1993).

For some industries, other intangible assets are the value of the brand name, product differentiation, and good will arising from product reputation. These assets are typically the product of advertising expenditures and investments in sales and service. Reporting by firms of advertising expenditures ( $\mathrm{Adv} / A)$, is taken as an indicator of the rents accruing to brand-name reputation.

Hall (1993) uses a proxy for any market power or long-run profitability of the firms that is not specifically related to advertising or R\&D inputs. Included in this study is a two-year moving average of cash flow (net of advertising and $R \& D$ expense, $C F 2 / A$ ). Also included is the growth rate of sales in the current year $(\Delta \log S)$ to capture the prospects for future growth of a particular firm which may be a product of R\&D and other investments but is not completely captured by the current level of R\&D capital or spending. (Hall, 1993).

The Appraisal of Real Estate, $10^{\text {th }}$ ed. (Rabianski, 1996), provides the following definition for going concern value:

"The value of a proven property operation. It includes the incremental 
value associated with the business concern, which is distinct from the value of the real estate only. Going concern value includes an intangible enhancement of the value of an operating business enterprise which is produced by the assemblage of the land, building, labor, equipment, an marketing operation". (Rabianski, 1996, pg. 190)

A more expansive definition of going concern value is given by Manning (1993):

The most probable market value, expressed in terms of money, available in the open market for a proven business enterprise that has established patronage, exclusivity or uniqueness, which results in demonstrated earnings or profitability. It incorporates the value of the real estate, machinery and equipment, working capital and all other assets that are in place, operating within and are a part of an established business. Included is the excess of value over cost that arises as a result of earnings capability in a complete and well-coordinated operation.

Manning (1993), also states that going-concern value is:

"The present value of surplus earnings after the costs of capital, labor, management, and real estate have been attended to" (Manning, 1993, pg. 6)

This last definition is conceptually different from the first of Manning's definitions. The latter definition views going concern value as the difference between the total market value of the business and the value of the business attributed to the factors of production or resources used by the firm. This definition is supported by Henszley (1983):

"The difference between the total value of a viable, operating business and the value of its tangible assets. In this context, going concern value is the intangible value that exists over and above the value of the intangible assets." (Henszley,1983, pg. 699)

In addition to real property, tangible assets are inventory and fixed assets such as "leasehold improvements, furniture, fixtures, and equipment, etc." Real estate includes: "land 
and the improvements placed thereon, quality and utility of the building, (and) location including an access and visibility, neighborhood and surrounding amenities." The tangible assets include: "machinery and equipment (or furniture and fixtures), the quality and use thereof, leasehold interest or advantage, efficiency of plant, (and) working capital. (Rabianski, 1996).

There are many reasons to analyze intangible assets ranging from income taxation to commercial litigation. Several of the valuation approaches presented in this thesis contain intangible values. The ability to identify intangibles for ad valorem tax purposes is important. Some states do not tax intangible property while others do. The intangible assets include the "leasehold, trade name, patents, copyrights, customer lists, goodwill, advantageous financing arrangements, etc." The intangible or goodwill portion includes: management expertise and ability, existing customer attitudes and patronage, stability of earnings generators and the capability thereof, (and) probability of profit continuance. The term "business enterprise value" also frequently arises in the discussion of surrounding going-concern value. Business enterprise value refers to the value component over and above the value of the real property. In this context, business enterprise value is an intangible component caused or created by entrepreneurial effort and managerial ability associated with and intrinsically involved in the conceptualization, planning, design, and assemblage of productive resources in the development as well as the construction and the operation of the business. (Rabianski, 1996).

Reilly and Dandekar (1997) present three common approaches to valuing intangible assets. The intangible assets considered in each approach are listed in table 3 . It is important to note that the most important parameter to valuing intangible assets is the premise of value. The "highest and best use" of the intangible asset usually dictates the appropriate valuation premise. 
Furthermore, the purpose and objective of the valuation normally dictates the definition of value and the premise of value. (Reilly and Dandekar, 1997).

Table 4.1. Intangible assets

\begin{tabular}{|l|l|l|l|}
\hline \multicolumn{3}{|c|}{ Common approaches to valuation of intangible assets } \\
\hline \multicolumn{1}{|c|}{ Intangible Asset } & $\begin{array}{c}\text { Market } \\
\text { Approach }\end{array}$ & $\begin{array}{c}\text { Cost } \\
\text { Approach }\end{array}$ & $\begin{array}{c}\text { Income } \\
\text { Approach }\end{array}$ \\
\hline Customer lists & & & $\mathrm{X}$ \\
\hline Corporate practices and procedures & & $\mathrm{X}$ & \\
\hline Contracts & & & $\mathrm{X}$ \\
\hline Computer software & & $\mathrm{X}$ & \\
\hline Copyrights & $\mathrm{X}$ & & $\mathrm{X}$ \\
\hline Franchises & & & \\
\hline Goodwill & $\mathrm{X}$ & & $\mathrm{X}$ \\
\hline Licenses and permits & & & $\mathrm{X}$ \\
\hline Patents - active & & $\mathrm{X}$ & \\
\hline Patents - inactive & & $\mathrm{X}$ & $\mathrm{X}$ \\
\hline Proprietary technology & & $\mathrm{X}$ & $\mathrm{X}$ \\
\hline Trademarks and trade names & & & \\
\hline Trade secrets & & $\mathrm{X}$ & \\
\hline Trained and assembled workforce & & \\
\hline Sal Ren & & \\
\hline
\end{tabular}

Source: Reilly and Dandekar 1997 
According to Rabianski (1996), market value of real property can be estimated using three evaluation techniques. This includes the sales comparison, cost, and income approaches. The question is whether these three techniques can capture the going-concern value that includes real property, fixed assets, and the intangibles. The cost approach to valuation is not structured to handle any and all aspects of the business. The cost approach to value real property cannot be modified to estimate the intangible aspects of a business according to the concept of goingconcern value and, therefore, cannot be used to estimate going-concern value. The intangible value would have to be separately estimated and added to the value of the real property and other tangible assets to get an estimate of going-concern value.

In the sales comparison approach, financial ratios such as operating expense ratio, debt service coverage ratio, and the equity dividend ratio can be used as elements of comparison to select comparable properties. These financial ratios are oriented toward the operation of the property rather than the operation of the business in the property. Financial ratios can be used to value a business and estimate the going-concern value of an operating business but the nature and substance of the ratios are different. The operating expense ratio focuses on operating the property, not operating the business. An operating expense ratio for the going business concern needs to consider business cost items such as the cost of goods sold and salaries/wages in addition to the property's operating expenses. Similarly, the appraiser's equity dividend rate is also a property concept. As a measure of return, it could be modified to include business revenue and business cost items to generate the numerator of the ratio, and it could be modified to consider all forms of initial equity required to start the business in addition to the funds needed to acquire the equity position in the property. (Coggins, 1998) 
A cash flow analysis (income approach) is the only applicable valuation technique for going-concern value. Either the direct or the yield capitalization approach can be used ${ }^{3}$. The form of cash flow statement must be modified, however, to include business revenue and cost factors that are not part of the revenue and cost factors for the operation of the property. (Rabianski, 1996).

According to Rabianski (1996), the intangible value of a business is the difference between the going-concern value of the business including the real property (GCV) and the market value of the real property (MV). The GCV is estimated using discounted cash flow (DCF) analysis or direct capitalization, and MV can be estimated using any of the three valuation techniques. To make the most conceptually appropriate comparison of GCV and MV, the income approach to MV estimation should be the technique used. The intangible value or the enterprise value of a business is positive if GCV > MV. The intangible value of a business could also be negative, GCV < MV. In this case, the business is not fully utilizing the potential for the subject property's space in the market.

\subsection{ECONOMIC RENTS}

While the basic model for structural and regulatory reform in electricity is fairly straightforward, the details of the institutional reforms that are necessary to improve on the performance of the present U.S. system are complex. Pressure for reform in the U.S. reflects rent-seeking behavior by various interest groups (school districts) pursuing private agendas that may not always be consistent with efficiency goals. At the same time, there are good public interest reasons to believe that structural reforms that foster competition can lead to real cost

\footnotetext{
${ }^{3}$ In literature, on business valuation, the capitalized earnings approach and the discounted future earnings methods are structurally equivalent to direct and yield capitalization, respectively.
} 
savings in the long run if appropriate supporting institutional arrangements are put in place. Because of the critical role that economic and reliable supplies of electricity play in the economy, there is a profound public interest in ensuring that these reforms improve rather than degrade the performance of the electricity sector over the long run. (Joskow, 1997)

Producer's surplus is normally used to measure the welfare effect of a policy on producers. In a pure perfect competition case, producers' surplus can only exist in the short run since, in perfect competition, long run equilibrium profits are driven to zero and there are no fixed costs. In reality, since producers are concerned with the short run and not the long run, producers' surplus is important. In the long run, there will be rents earned by certain limited resources such as land and patented factors of production or technologies. (Tollison, 1982)

Historically, economic theory defines rents as earnings in excess of what it takes to keep an input in its current employment. Some classical economists used to argue that rents were evil and should be taxed away. Henry George is associated with developing the land tax and this practice continues today with the use of real property taxes. More modern analyses have indicated that rents are endemic and fundamental to natural resource industries. All of the earnings of a natural resource such as coal or oil in excess of the costs (including capital costs and minimum return on investment) of extraction and refining are rents. (Krueger, 1974)

All rents share one common factor in that they are earned by a factor or resource that is limited in supply. This factor can be a limited factor such as managerial talent, location, environmental quality, or natural resources. It can also be an artificially induced limitation such as a patent, copyright, or monopolization of a market. Rent can be very important in determining the price of a resource. The price paid for land is based entirely on the present value of the stream of rents generated by that piece of land. Those rents are determined by land quality, 
location, environmental characteristics, and the demand for the services provided by the land. Resource valuation and environmental economics are both based on determining or estimating the rents generated by the resource.

It is important to realize that only the initial owner of the rent generating resource earns the rent (in the form of excess profits). This occurs because the rents are capitalized into the price of the resource. Any future buyers pay a price that reflects the present value of the rent.

\subsection{RISK}

According to Hayward and Schmidt (1999), risk has two components - systematic and unsystematic. Systematic risk concerns the changes in economic, social, and political conditions that affect the risk structure and market prices of securities. These changes include expected inflation and the real risk-free rate. The real risk-free rate is the price of postponing consumption by one year and is derived by the supply and demand for money in the economy. The real riskfree rate is the return required by investors if inflation and risk did not exist. The 91-day U.S. Treasury Bill is often used as a proxy for a risk-free rate. A 91-day Treasury bill is considered risk-free since usually little, if any, inflation can occur in 91 days, and the U.S. government has never defaulted on its debt. The real rate represents the underlying long-term growth rate in the U.S. economy.

Unsystematic risk involves business and financial attributes specific to a company and industry that cause shareholder returns and stock prices to vary. Through diversification, investors can substantially reduce the variations in returns caused by unsystematic risk. Systematic risk cannot be diversified away, however, since the social, economic, and political 
factors influencing this component have an impact on all securities to a certain extent. (Chen, 1967)

One way to incorporate risk is to adjust the discount rate. The net present value (NPV) is the present value of yearly income less the present value of all yearly costs, including investments. The NPV can be calculated by applying a discount rate which can be adjusted to incorporate risk. The discount rate is the rate used to discount future cash flows (revenue and costs) to determine present value and reflects the opportunity cost of capital to the firm (Torries, 1996).

\subsection{CAPITALIZATION RATE}

A capitalization rate is an expected rate of return that investors would require to invest in a property. It is an expected rate of return that an investor could get from another equivalent risk property. The capitalization rate, often referred to as the current cost of capital, is dependent on risk - the higher the risk the higher the rate. If a given property is typically financed by both debt and equity, then the capitalization rate will include both financial and business risk. (Assessor's Handbook, 2000).

The purpose of a capitalization method is to convert future income into value.

Capitalization methods are described by the shape and duration of future income. Future income may last forever or it may terminate; it may incline, remain level, or decline; or it may have some combination of these characteristics. Capitalization methods based on terminating income projections are generally applied in conjunction with traditional land and building residual techniques or property reversion techniques while direct capitalization methods are used with perpetual income flows. (Assessor's Handbook, 2000). 


\section{Chapter 5}

\section{Asset Valuation Methods}

\subsection{BASICS OF ASSET VALATION}

The basics to any asset valuation analysis must consider the following fundamentals (Hayward and Schmidt, 1999 and Torries, 1996):

- The analysis of historical data

- Estimating future earnings before adjustments for interest expenses, income taxes, depreciation, and amortization expenses - both the timing and the amount.

- Estimating the capitalization or discount rate that will be used to calculate the present value or today's value of the future income stream (sometimes the weighted average cost of capital (WACC) is used.

- Estimating the present value of the future income stream (i.e., the value of the future income stream in today's dollars).

- An analysis of the risk involved in choosing among the different valuation methods and identifying the user's perception and tolerance to the risks involved.

- Attempt to determine a single unit value for the purpose of taxation, sale/purchase or investment.

- Analyzing and interpreting the results.

\subsection{VARIABLES AFFECTING THE VALUE OF A UTILITY}

Timing and the amount of income as well as the Discount/Capitalization rate primarily affect the value of electric utility assets. According to Hayward and Schmidt (1999), there are also a number of not so obvious factors that can affect asset values. These are:

- Reserve margin or the amount of generating capacity available above peak load. An abnormally high reserve margin might suggest under-utilized plant (over-capacity). Such over-capacity may not generate income for several years into the future. 
- Pricing flexibility. If the utility is limited to charging only tariff-based rates and does not have the ability to adjust prices to meet competitive alternatives, sales from the utility's assets may be lost. Prices in competitive markets can vary only slightly (if at all) between alternative producers. Indeed, prices between homogeneous products can differ only by insignificant amounts before purchasers buy from other suppliers or produce the product themselves. In the case of electricity, there are no inherent physical differences in the electricity produced by different suppliers or self-generation. Therefore, pricing flexibility is essential if the asset is to compete. If the asset cannot produce a competitively priced product, the value of that asset is adversely affected.

- Transmission access. An isolated generation plant, for example, with limited transmission access has limited markets. Limited markets may not enable sales to higher priced $\mathrm{m}$ arkets, thus trimming potential profits. Reduced profits translate into reduced value.

- Sales mix. A high concentration of price-sensitive industrial customers could present challenges. It is difficult to compete on price alone.

- Cost structure. The utility's cost structure, particularly the utility's embedded and marginal cost of power generated, must be compared to other sources of generation that have access to the utility's market area.

- Regulatory prices. Regulatory prices can significantly affect the value of an electric utility's assets. Basic policies such as allowed rate of return, the use of a future versus historical test year, fuel adjustment clauses, incentive mechanisms, and the regulator's record of disallowance for imprudent investments are fundamental factors that can affect the value of an electric utility or its assets.

- Long term power supply contracts. Just having the contract itself and the relative certainty of the income associated with that contract can be of significant value to the purchaser. Such contracts also help in financing the acquisition of the asset.

- Physical condition of plant and equipment. Necessary repairs and/or deferred maintenance can influence significantly the value of the asset or utility. It is important to assess the need for these items before the purchase is determined. Such factors can be a critical negotiating tool.

- Location, location, location. The present and future value of the land on which the asset is located could be worth a great deal. Perhaps even more than the asset itself because of it's access to a market even for new construction on that site.

- Management. The utility's management can significantly affect the value of an electric utility and its assets. Judgment calls on maintenance issues, customer relations, political issues, union versus non-union labor, labor wage rates and policies, the ability to motivate employees, shareholder relations, and a host of other factors can influence the productivity and value. Perhaps this is why the asset can fetch a higher price in the first 
place. In such cases, the new management (and their investors) are of the opinion they can do a better job than the old, especially if the old management is focused on an outmoded paradigm.

Environmental factors are another consideration when determining value. In a competitive market, the cost of environmental compliance will no longer be included in rate base or the regulated cost of service. This will increase the cost burden on a utility generator. Older plants, which usually require more environmental modifications, will incur more significant costs. Prospective investors in a power plant will recognize environmental changes that may affect the profitability of their investment. (Schneider, 1998).

The Securities and Exchange Commission has addressed the accounting and disclosure of environmental liability costs. The commission has acknowledged that even though estimates of environmental liabilities differ from actual amounts, electric utilities may not delay recognition of a contingent liability until they have a reasonable estimate. The electric utility should measure its potential liability in light of facts, laws and regulations, and existing technology. Furthermore, the entity should incorporate expected inflation, societal, and other factors in its measurement. They also state that even though regulators decide if an environmental cost is capitalized or expensed, the regulator cannot affect the timing of the recognition of the liability. (Hayward and Schmidt, 1999).

Computing the capitalization/discount rates for a valuation project can also have an effect on the outcome of the valuation. Capitalization and discount rates are often discussed as if they are one in the same but there are fundamental differences in concept, application and computation (Bizyak, undated). A utility's cost of capital is its discount rate. Included in the cost of capital are three specific elements of investor expectation. These include:

- A "real" rate of return for use of investor dollars by someone else on a risk-free 
basis,

- Expected inflation compensation for reduced future purchase power, and

- Risk as to the future cash flow or other economic benefit stream.

Cost of capital has several characteristics:

- It is market driven - an opportunity cost

- It is a function of the investment, not the investor,

- It is forward looking and based on expected returns,

- It is measured against market value, not book value, and

- It is usually stated in nominal terms, i.e., including inflation expectations.

The cost of capital is a link called the discount rate that equates expected future returns for the life of an investment with the present value of the investment at a given date. A discount rate can be observed from historical company or industry cost of capital experience and future cost of capital expectations or it can be developed from several different models that are widely utilized within the business community. Once developed, the discount rate is utilized to determine present value factors to be applied to future projected economic benefit streams to discount those streams to present value. (Bizyak, undated).

In assessing the value of a privately held operating business, no methodology more closely mirrors the theoretical definition of fair market value (FMV) than the discounted future benefits (DFB) method under the income approach. The DFB method entails the projection of future cash flows and then "discounting" the future cash flows to today's dollars using an appropriate rate of return. The discount rate essentially assimilates the rate of return necessary to attract investors to the particular company with all its attendant risks or other investments with similar risks. Numerous methodologies exist for determining the discount rate. The two most common methods are the capital asset pricing model (CAPM) and the buildup model. The 
starting point in developing a discount rate is to identify a "risk-free" rate. The risks for a competitive electricity industry involve market prices for electricity as well as fuel costs. No investment is totally risk-free and most business professionals use the twenty-year U.S. Treasury bond rate. (Grossman, 2000)

The risk-free rate is comprised of three elements. First it includes "rent" for foregoing consumption and use of the investor's money. Second it includes a risk premium for interest rate risk. Lastly it includes a risk premium for investor expectations about inflation. This is where the twenty-year bond is used. Once identified, the risk free rate is increased by a premium that reflects the additional return required by investors to buy equities in the public market versus investing in Treasury bonds. Various sources serve to identify this premium but the most common is Roger Ibbotson's Stocks, Bonds, Bills, and inflation yearbook. (Grossman, 2000). In contrast, a capitalization rate can be directly observed in the public market if comparable companies can be identified. Alternatively, a capitalization rate can be determined by subtracting from the discount rate the company's expected long-term sustainable growth rate applicable to the economic benefit stream being utilized. While a discount rate is applied to all expected incremental returns to discount the benefit stream to present value, a capitalization rate serves as a mere divisor to one single element of return. Seldom will these two rates be the same. The only instance in which the discount rate is equal to the capitalization rate is when each future increment of expected returns are in perpetuity. In every other situation the rates will be different. The fundamental principle in the valuation of utility assets is that the value of the asset is equal to the present value of its future cash flow. 
Table 5.1. Capitalization rate

\begin{tabular}{|lc|}
\hline \multicolumn{2}{|c|}{ Development of Capitalization Rate } \\
\hline Discount rate & $25.0 \%$ \\
\hline $\begin{array}{l}\text { Long Term Sustainable } \\
\text { Growth Rate }\end{array}$ & $(4.0 \%)$ \\
\hline Capitalization Rate & $21.0 \%$ \\
\hline
\end{tabular}

Source: Grossman, 2000

Interest Rate/Weighted Average Cost of Capital (WACC): An electric utility's WACC is important because it serves as the capitalization/discount rate to convert the utility's future stream of cash flow into a present value that is important to investors debt and equity.

WACC consists of the cost of each element in the capital structure (i.e. short-term debt, long-term debt, preferred stock, and common stock). The cost of each of these items and the capital structure should be based on the future. The utility's WACC reflects investors' expectations as opposed to historical data that is not necessarily reflective of future performance.

The formula for a utility's WACC is as follows:

$$
\mathrm{WACC}=\mathrm{Kb}(1-\mathrm{T}) *(\mathrm{~B} / \mathrm{V})+\mathrm{Kp} *(\mathrm{P} / \mathrm{V})+\mathrm{Ks} *(\mathrm{~S} / \mathrm{V})
$$

Where:

$\mathrm{Kb}=$ the market pre-tax cost of nonconvertible and noncallable debt

$\mathrm{Ks}=$ the market cost of common equity capital

$\mathrm{Kp}=$ the market cost of preferred capital

$\mathrm{T}=$ the marginal tax rate of the electric utility being analyzed

$\mathrm{V}=$ the market value of debt, common equity capital, and preferred capital

$\mathrm{B}=$ the market value of interest-bearing debt

$\mathrm{P}=$ the market value of preferred stock

$\mathrm{S}=$ the market value of common equity

The WACC should represent the marginal cost of all sources of capital. Marginal cost is the cost of new capital. Marginal costs are used because investment decisions should be based on the current cost of capital instead of an electric utility's existing or embedded cost of 
capital. The WACC must also be based on the after-tax cost of capital since the WACC is applied to after-tax cash flows. Finally, the WACC must be consistent with the various weights (or percentages of capital) in an electric utility's capital structure. The capital structure represents the percentages of each type of capital. The sum of the percentages must equal one. It would be incorrect to have a very high percentage of debt in the capital structure and relatively low costs of long-term debt and common equity. (Hayward and Schmidt, 1999)

The terms "capitalization rate" and "discount rate" are often used interchangeably but this is incorrect. To distinguish between the two terms it is necessary to look at the terminal value or lump sum in a series of cash flows. If a terminal value does not exist then the use of a capitalization rate is appropriate. In that case, one WACC rate is used to discount the yearly amounts of cash flows each year to infinity. When a terminal value does exist than a discount rate should be used. In this case, a WACC rate is used to discount both the yearly amounts of cash flows and the lump sum terminal amount.

\subsection{VALUATION METHODS}

\subsubsection{COST APPROACH}

According to Youngman (1994), the cost approach "estimates market value on the basis of a property's cost of construction, reduced to reflect obsolescence and physical depreciation" (Youngman 1994, pg.34). According to Torries (1996), major cost categories consist of Direct Operating Costs, Net Production Costs, Cash Break Even Cost and Total Cost. Total Cost is actually the summation of the other cost categories.

In her book, Legal Issues in Property Valuation and Taxation: Cases and Materials, Youngman, (1994) defines the cost approach as involving a determination of the current cost of 
reproducing property less loss in value from deterioration and functional and economic obsolescence-accrual depreciation. There are five steps involved in the cost approach:

- the estimate of the land value as if vacant,

- the estimate of the currents cost of reproducing or replacing the existing improvements

- the estimate of accrued depreciation from all causes,

- deduction of accrued depreciation estimate to arrive at indicated value of improvements,

o the addition of the land value to the indicated value of the improvements to develop indicated property value.

In information filed to the West Virginia State Tax Department, the cost approach for an electric generation facility includes:

- Electric generation facility in service

- Materials and supplies

Less:

- Locally assessed property

- Pollution control facilities

- Plant under capital lease

Less:

- Depreciation

Plus:

- Depreciation on Locally assessed property

- Depreciation on Pollution control

The cost approach is considered a meaningful tool for estimating market value under certain conditions. Three cost concepts have potential application to utility properties -replacement, reproduction, and historical. The relevance of these concepts vary depending upon economic and regulatory influences on the market. (Assessor's Handbook, 2000) 
Reproduction cost may be different from replacement cost. It is the cost of an exact duplication insofar as is possible of an existing facility. This cost concept also has relevance as a value indicator whenever the market forces permit returns satisfactory to investors. Replacement cost, in comparison, is the estimated cost to construct a property that is equivalent to the property being appraised in terms of utility as of the valuation date. It is this concept of cost that is validated by the principle of substitution since a rational person will pay no more for a property than the cost of acquiring a satisfactory (not necessarily identical) substitute property. In the case of electric utility generators, the most desired and efficient plant replacement would be gasturbine technology.

The most difficult aspect of the replacement cost approach is estimating depreciation. Depreciation is the difference between the present value of the property being appraised and the present value of a hypothetical newly built modern plant of equivalent utility. The three generally accepted means of estimating depreciation include the market method, the percent good method, the straight-line or age-life method, the observed condition method, and the production output or services hours' method.

According to the Assessor's Handbook (2000), most assessors use the percent good factor. To say a plant is $80 \%$ good is to say that depreciation is $20 \%$. The calculation for replacement cost new is:

Replacement Cost New $(\mathrm{RCN}) \times \%$ good factor $=$ Replacement Cost New less Depreciation.

This produces an estimated market value for each type of property. The summation of all these properties is the estimated market value of the unitary property from the cost approach. 
Some adjustments to the initial value indicator should be considered. These include but are not limited to:

- Nontaxable property and property assessed elsewhere

- Construction work in progress

- Leased property

- Taxable possessory interests

- The value of property that is exempt from taxation (including the value of intangible assets and rights) or the value of property that is taxed in a different manner should be excluded from the replacement cost indicator.

\subsubsection{INCOME APPROACH}

Youngman's (1994) definition of the income or earnings approach "determines value by reference to the property's income-producing capacity under typical management." (Youngman, 1994, pg.35). The four steps involved in the income approach involve:

- Obtain the rent schedules and the percentage of occupancy for the subject property and for comparable properties for the current year and for several past years. This information provides gross rental data and the trend in rentals and occupancy. This data is then compared and adjusted to an effective estimate of gross income, which the subject property may reasonable, be expected to produce.

- Obtain expense data, such as taxes, insurance and operating costs being paid by the subject property and by comparable properties. The trend in these expenses is also significant.

- Estimate the remaining economic life of the building to establish the probable duration of its income, or, alternatively, estimate the suitable period of ownership before resale.

- Select the appropriate capitalization method and the applicable technique and appropriate rate for processing the net income.

The income approach to value is considered an excellent method to estimate 
market value if reliable economic data are available. Application of the approach requires estimating future annual income and converting that income into a value estimate by means of a capitalization rate. The critical ingredients of the approach are future income, duration of the income, capitalization rate, and method of capitalization. (Assessors' Handbook, 2000) Income can be defined as the amount of money a project produces after expenses (except depreciation), but before interest and income taxes are paid. Depreciation is the recovery of a non-cash yearly expense based on the original investment and age of the asset. The capitalization rate or discount rate is the cost of money, including debt and equity. It is used to calculate the present or future value of income at a particular point in time. Capital structure is that proportion of an electric utility's debt and equity.

Valuing an electric utility involves estimating future economic performance. There are several ways to define the financial performance of an electric utility. Estimating "free cash flow" is the most important measure of "earnings" for valuation purposes. Earnings are also called net income or profit. (Hayward and Schmidt, 1999).

The income to be capitalized is future net income that can reasonably be anticipated by a prospective purchaser. This "principle of anticipation" was explained by the Court in De Luz Homes, Inc. v, County of San Diego, (1955) 45 Cal. 2d 546, as follows from Bonbright.(1937):

The net earnings to be capitalized,... are not those of the present owner, but those that would be anticipated by a prospective purchaser. 'Anticipated future earnings is the sole matter of consequence, since reported earnings are already water under the mill.'

Income forecasting is usually done at the net income level. A current annual 
gross income estimate for the property is reduced by normal operating expenses to arrive at net income. The appraiser then estimates what shape that net income will take in the future. It is this future net income stream that is capitalized into value.

Income projections for utility property normally start with an analysis of current financial statements since investor decisions are based on this same data source. For growth-oriented properties analysis of the current year's operating statements is usually preferable; past earnings may give little insight into the future when annual investments in new plants are in millions of dollars. For nongrowth companies, it may be reasonable to analyze past earnings over a longer period of time. Some appraisal authorities advocate analyzing at least a five-year history of earnings in order to level out the peaks and valleys. Income projections, however, should be based on the purchasing power of the dollar as of the appraisal date. Averaging five-year old dollars with current dollars may result in major income distortions because of inflation. Inflation can be treated consistently by adjusting historical earnings to current dollars prior to using that data to forecast future income; consistent application requires capitalizing income at a rate based on the current cost of capital. (Assessor's Handbook, 2000)

Analysis of operating statements may require reconstructing income and expenses for various reasons. For example, recent rate changes, which are not fully reflected in current operating statements, may have to be adjusted to a full year basis. Similarly, expenses that are unusual and nonrecurring may have to be deleted. The objective of this analysis is to arrive at a net income figure that, from a buyer's viewpoint, is probable and likely for the subject property. For property tax purposes, the level of income that is capitalized is typically a "net" income prior to any deductions for interest, corporate income taxes, ad valorem taxes, or depreciation. Interest expense is an indication that a portion of the capital is borrowed, and this fact should not lower 
the value of the unitary property. Debt interest expense is accounted for in the capitalization rate, so interest cannot properly be deducted from income as an expense. Corporate income and ad valorem taxes are legitimate operating expenses and must be considered as such. Tax allowances should approximate the amount of taxes that would be anticipated by a prospective purchaser. Since both income and ad valorem taxes are a function of either income or value, and since both income and value are being estimated, it is preferable to provide components in the capitalization rate for these taxes instead of deducting them from income. State income and ad valorem tax components cannot be accurately estimated for interstate companies because out-ofstate tax rates necessary for the computation are usually unknown to the appraiser, so in those cases such taxes should be directly deducted from income. (Assessor's Handbook, 2000)

Depreciation, as reflected in operating statements, is not such a cash outlay but rather a bookkeeping allocation of a portion of a prior accounting period's investment to current expense. Therefore, for purposes of income capitalization or discounting a cash flow, book depreciation is not an expense. In the De Luz decision, the court dealing with the question of expensing depreciation pointed out that to estimate depreciation the appraiser must preconceive a capital value and that to include an expense based on the very answer you seek is an error. The investor, however, is entitled to recapture his investment as well as earn a return in it. The court further held that capital recovery is correctly handled by including a recapture component in the capitalization rate. (Assessor's Handbook, 2000)

The behavior or shape of the future income stream must be estimated and projected over the remaining life or expectancy of the unitary property. An exact prediction of the behavior of income is not possible or necessary. It is sufficient to estimate future income behavior that a prospective purchaser would anticipate. The purchaser's estimate would be based upon the 
probable or likely "net income" or cash flow over time. Actual incomes fluctuate, but an estimate by a buyer would likely be a smoothed or averaged income projection. (Assessor's Handbook, 2000)

Growth in the consumption of the services or product on a per customer basis has been characteristic of the utility industry. The growth rate varies among utilities and can be expected to continue to vary depending, in part, on spatially diverse regulatory attitudes about conservation. The growth in consumption per consumer causes income to rise. Another factor that needs to be considered when projecting income is that as assets are used and become older, there is a tendency for their efficiency to decline. This decline in efficiency causes costs to rise and may cause net income to decline. All of the above factors complicate the estimation of the behavior of the income stream. Some plausible arguments can be advanced for using either an inclining income premise or a declining income premise. A constant or level income premise may be the best fit if the factors influencing income changes are offsetting. In any event, the appraiser's estimate should fit the expectations of investors who constitute the market for the property being appraised. The income premise selected is only an estimation or projection of the probable behavior of the income over time. It is not used as a means of providing for risk or the likelihood that the income will or will not be received. Those factors are properly reflected in the capitalization rate. (Assessor's Handbook, 2000).

Utilizing the income approach requires the estimation of the duration of a property's earning potential. Land has the capability to earn income forever while improvements and personal property have limited economic lives. Utilities are made up of a large percentage of assets that have terminal lives. These assets are continually replaced so that in reality the companies have infinite economic lives. 
In some states, the unitary value of a utility must reflect only the value of the property that exists on the lien date. Future income growth and endurance resulting from future investment should not be considered in the income amount and duration estimates unless the costs of these future investments are expensed from the projected income stream. Otherwise, this may result in valuing property that does not exist on the lien date.

Capitalization of income for a limited duration requires an estimate of remaining life. Under the unit concept, the net income stream should not be fragmented but rather should be capitalized in total for a single period. A composite life expectancy can best be estimated by analyzing the life expectancies of the various assets that make up a company's unitary property. There should be a weighting of relative importance of each asset's contribution to remaining life; this weighting can be done on the basis of historical, reproduction, or replacement costs. Replacement cost is considered the best premise because it gives consideration to current price levels.

Capitalizing income on a perpetual basis requires making in-depth studies of replacement costs and replacement patterns. The replacement costs of assets having the same quality and capacity as the existing assets must be deducted from the income stream. It is this provision for future replacements, above and beyond the normal maintenance and repairs associated with the unit that perpetuates the income life.

A major problem with the approach is that most replacements are not exact replacements; they are also improvements which increase plant quality and capacity. Utilities not only upgrade but they also maintain their operations. If the cost of investment in new plant or replacements that increase capacity is to be expensed against income, then the projected 
income stream must also include the income potential of the future investment. (Assessor's Handbook, 2000).

The income method approach assumes that property is worth the present value of the income stream it can generate. Under traditional regulation, utilities project future income based on rate of return on rate base discounted by the market cost of capital. If market cost of capital approximates the allowed (and assumed achieved) rate of return, the income indicator will approximate the rate base.

Under deregulation, an appraiser must estimate prospective income a utility's generating plant is expected to earn based on a reasonable projection of electricity market prices and how they will affect the plants dispatch. Operating costs, such as fuel prices, also are projected and discounted to present value. To make these projections, an appraiser can commission studies from energy and economic forecasting firms specifically for the plant at issue or use reports from the Energy Information Administration or the Gas Research Institute, which provide a more global perspective. The utility can also use price projections that it has used to conduct studies of stranded cost recovery. These studies typically provide the portion of net book cost the utility would likely not recover, and by extension, what an investor likely would not purchase. If the assessment is based on net book value, such studies will prove useful to benchmark property values. Depending upon the quality of the study, it may be combined with competent appraisal evidence and used to prove a value reduction in court. If a plant is already producing primarily for a wholesale market, then competitive prices could be projected. State law should be examined to determine if using an income stream based on rate base or including stranded cost recovery allowances would improperly set the value of the property based on the owner's use rather than its FMV or by valuing intangible assets. Fair market value 
is based on hypothetical buyers and sellers in the marketplace. If the only buyers would be independent power producers, their purchase price would be based only on the value of the tangible assets. Only the utility-not an independent power producer-would have the ability to collect both the income from rate base or stranded costs. Under most state laws, prices from above-market power purchase agreements should not be used to project income since doing so will value the non-taxable intangible contract rights rather than the tangible property comprising the power plant. (Schneider, 1998).

\subsubsection{COMPARABLE SALES APPROACH}

The comparable sales approach or market data approach involves an analysis of sales of property similar to the property under question (Youngman, 1994). This approach involves five steps:

- Research similar properties for which similar sales, listings, offerings, and/or rental data are available.

- Determine the nature of the conditions of the sale, including the price, terms, and motivating forces.

- Analyze each of the comparable properties' attributes with those properties being appraised under the general characteristics of time and location including physical and economic characteristics.

- Consider the dissimilarities in the above step in terms of their probable effect on the sale price.

- Determine in light of the comparisons an opinion of the relative value of the subject property as a whole or by applicable units being compared to similar properties.

In a hearing before the West Virginia Public Service Commission

(Chernick, 1999), testimony was given as to the market value for generation assets of West

Virginia utilities. This market value was based on an analysis of the actual prices of comparable 
capacity sold for use in the electric generation market. In this analysis it was concluded WV generating assets exceed book value implying a negative stranded cost.

Auction, sale, spin-off, or some other market process implements market valuation methods. In a study of electric transition costs (Hirst, Baxter, and Hadley, 1997), the contention is that the sale price obtained through an auction, by comparison, defines the current market price of an asset. The sale price should reflect the buyer's estimate of the net present value of the revenues to be generated by the asset (electricity produced and the market price of power) minus the ongoing costs of the asset (fuel plus O\&M), plus any salvage value. Auctions eliminate the need for regulators to estimate future production, book value, or market prices for electricity. All of that is left to the bidders.

Based on testimony before the WV PSC, Howard W. Pifer III (1999) testified as to the drawbacks of the comparable cost approach of valuation. The main argument is that "comparables" are not always comparable. When comparing generation assets it should be noted what the similarities and differences are among the assets. Location is important because of access to fuel sources and to transmission facilities and consumers. Other considerations are that the "potentially stranded assets have to be very similar in operating parameters and costs and in the same market as the candidate comparable transaction, or the prices of the candidate comparable transactions must be quantitatively adjusted to account for any differences".

The comparative sales approach is seldom applicable to utility properties since they infrequently sell. Moreover, the few sales that do occur are difficult to analyze because such transactions usually include subsidiary companies, have complicated financial arrangements, and often include only a portion of the unitary property. The approach should not 
be ignored when sales exist, but careful analysis is required before a sale can be used as an indicator of value.

The market value concept assumes a typical prospective buyer exists for the property being appraised. Since utility properties are unique and rarely sold, the type of buyer is reasoned to be someone who would use the property in a similar manner as the present owner unless the property clearly has a more probable use. The prospective buyer would have a similar capability, knowledge, and credit rating as the present owner and would take ownership of the property under the assumption that ad valorem and income taxes would continue. In California, where electric generation deregulation has been ongoing, utilities have sold portions of unitary properties, such as distribution systems and rights-of-way, to tax exempt agencies. Since taxexempt agencies usually do not pay ad valorem or income taxes, do not have rates that are regulated, and can borrow money by issuing tax-exempt securities, they have many advantages that do not exist for a typical buyer. (Ruff, 1999). These advantages, together with the right of condemnation, have resulted in the sales prices of such properties taking place at amounts equivalent to reproduction cost less depreciation. Such sales do not meet the definition of a market value transaction and should not be used as an indicator of market value. Moreover, the sale of a fractional part of a unit has doubtful validity as an indicator of the value of an entire unit. (Assessor's Handbook, 2000)

Usually corporate acquisitions are accomplished by mergers. In these cases, control of the corporation's assets is acquired. While such acquisitions are not outright sales of the tangible assets subject to ad valorem, they are the equivalent of sales of the assets since complete control of the assets is acquired. Application of the comparable sales approach must include analysis of these transactions. 
The market-comparable approach considers numerous factors simultaneously and provides a straightforward characterization of how investors perceive value. The marketcomparable approach's foundation is the identification of market transactions comprising either the acquisition of power assets or the purchase of publicly traded securities of companies that operate power assets. Thus, the market approach can be segregated into two subsets: the capitalmarket approach and the comparable-transaction approach.

The comparable-market approach compares the subject facility with public companies that possess similar growth prospects and business risks that trade on organized capital-market exchanges. The comparable public companies should exhibit characteristics that are representative of an independent power plant. Companies that develop and operate independent power plants are considered comparable companies when they exhibit characteristics that are consistent with the subject facility.

With the capital market approach, the capital markets in the form of a price-to-earnings ratio incorporate an investor's expectations concerning future cash flows and the perceived risk of the earnings. The price-to-earnings ratio offers a measure of investors' expectations concerning the perceived attractiveness of future cash flows. The product of the price-tooperating earnings multiple and the facility's operating earnings provides an estimate of the value of the facility. (Ellsworth, 1994)

\subsubsection{STOCK AND DEBT APPROACH}

The stock and debt approach is another method for valuing utilities. A study

of the yield and direct capitalization methods of the electric utility industry was conducted to determine the accuracy of this method for appraisal purposes. (Simonds, 1999) In this study current stock prices of the subject firms were observed. The empirical results suggest that direct capitalization is a more accurate estimation procedure than yield capitalization. 
According to the Assessors' Handbook (2000); the stock and debt approach is based upon the accounting equation that the value of the assets equals the value of the liabilities plus net worth. Market values of the long-term debt, current and deferred liabilities, and capital stock are estimated, and the sum of these amounts is held to equal the value of the total corporate assets. The value of the total corporate assets includes nonunitary and nontaxable assets; therefore, value allocations and deductions must be made to arrive at a value estimate for the unitary property. These value adjustments should be made on the basis of the value the securities market places on the deductible assets. In some cases, a further allocation is required to separate West Virginia property from property located in other states.

The stock and debt approach has many limitations. It cannot be applied to all companies because sometimes there is little or no trading of the securities. Furthermore, a utility may be part of a larger holding, and the parent company may be involved in other financial endeavors. The necessity to use a series of allocations, including allocations between companies and between states, greatly weakens the validity and reliability of the approach.

Another major limitation occurs when the stock and debt approach stems from the nature of the rights involved in a stock transfer. The usual purchaser of stock acquires ownership rights in the corporation, but this is an ownership without control. The stockholder has the right to vote, but he has no effective control or liability such as occurs when someone buys property in his own name. The purchase of enough stock to actually gain control of the corporation is usually made at a price higher than the price at which the stock is typically traded. A study of tender offers will illustrate this contention. This may indicate that typical stock prices do not effectively measure the advantages of ownership and control, which are inseparable in noncorporate property. Despite these limitations, the stock and debt approach has some validity. 
Well-informed investors do acquire stock based on analysis of a company's present and future earning capacity. The approach is meaningful when market participants have sufficient information to accurately measure the present value of future benefits likely to accrue to the corporation. (Assessors' Handbook, 2000)

The first step in applying the stock and debt approach is the valuation of the common and preferred stock and the long-term debt. Valuation is based upon the prices paid in the securities market. The data from more actively traded and widely held securities are presumably more accurate. If the securities are not traded, the validity of the approach is questionable. However, it is possible to use the method if some of the debt is not publicly held by estimating its value on the basis of the prices of comparable securities. It is also possible to use the method if a reasonable market price for the common stock can be developed.

The use of sales prices can be a problem since prices of securities usually fluctuate daily. Some experts believe the lien date price should be used; others feel an average of prices is preferred. In most case, the average of monthly high and low prices for the previous calendar year is used in order to eliminate any unusual or temporary market reaction not related to the value of the property.

The value of current and accrued liabilities, with some exceptions, must also be included in the gross stock and debt value. Current liabilities represent short-term debt and are a source of money or credit that can be used for the acquisition of assets. Current liabilities are usually valued at book value. However, dividends declared unpaid are a liability, which is not included in the gross value because this value is already reflected in the stock prices.

Each one of the accrued liability accounts must be considered and, if it is a source of money or credit that can be used for the acquisition of assets which add to the value, it must be 
included in the gross stock and debt value. Some deferred credits may be worth less than book value. Each account must be considered on its own merits and a determination made as to whether it should be included in the gross stock and debt value.

If leased property is included as part of the appraisal unit, the value of such property must also be added to the gross stock and debt value. Leased assets are not part of the unitary property in some cases.

Certain deductions are made from the gross stock and debt value. Deductions are itemized and should be made at the value placed on the asset by the securities market because the gross value is based on the securities market. Current assets are deducted since these represent cash and special deposits and notes and accounts receivable, which are nontaxable items. Prepayments are also deductible since no asset is on hand. Materials and supplies are deducted initially and added back since they represent a part of the subject valuation. Other deferred charges are also deductible. Book cost is presumed to be a good measure of the value of the deductible assets. 


\section{Chapter 6}

\section{Power Plant Valuation}

\subsection{INTRODUCTION}

To demonstrate how each valuation approach determines value, an example of each is applied to Appalachian Power (AP) assets. Information on AP assets was obtained from the West Virginia (WV) State Tax Department. This information includes, costs, income, and financial data necessary to conduct the income, cost and, stock and debt approach. Information for the replacement cost and comparable sales approach was obtained from the EIA and documented testimony before the WV Public Service Commission.

\subsection{VALUATION OF APPALACHIAN POWER PLANTS IN WEST VIRGINIA}

The following tables outline four valuation assessments for AP assets. The first three approaches (cost, income, stock \& debt) are valuations based on information from the West Virginia State Tax Department. Data used to conduct these valuations are held at the state tax department. Some of the financial data are considered sensitive and are not reported. These valuations are based on calendar year 1998 and were to be utilized for the 2000 tax year.

\subsubsection{COST APPROACH}

The WV cost approach is based on historical costs to include original construction and any improvements in the form of materials and supplies. This original cost is depreciated to obtain book value. Other considerations are the investment in pollution control facilities and any capital leases, if any. Allocations refer to the percentage of value that is taxed by the state of WV. Table 5 provides a summary of the data provided by the WV department of taxation that are the basis of the cost approach valuation for AP assets in WV. 
Table 6.1. Cost approach for AP assets

\begin{tabular}{|c|c|c|c|}
\hline COST APPROACH & SYSTEM (\$) & WV (\$) & WV ALLOCATION (\$) \\
\hline Plant in Service & $4,877,421,785$ & $2,828,319,482$ & \\
\hline Materials \& Supplies & $+87,360,815$ & $+\underline{55,999,332}$ & \\
\hline SUB TOTAL & $=4,964,782,600$ & $=2,884,318,814$ & \\
\hline $\begin{array}{l}\text { Less: } \\
\text { Locally assessed property }\end{array}$ & 0 & $-3,293,572$ & \\
\hline Pollution control facilities & 0 & $-308,553,684$ & \\
\hline Plant under capital lease & 0 & $-2,572,471,558$ & $51.8144 \%$ \\
\hline $\begin{array}{l}\text { Less: } \\
\text { Depreciation }\end{array}$ & $-1,952,792,667$ & $-1,243,471,558$ & \\
\hline $\begin{array}{l}\text { Plus: } \\
\text { Depreciation on locally assessed }\end{array}$ & 0 & 0 & \\
\hline Depreciation on pollution control & & $+158,374,217$ & \\
\hline SUB TOTAL & 3,011,989,933 & $1,487,349,872$ & $49.3810 \%$ \\
\hline $\begin{array}{l}\text { Less: } \\
\text { Obsolescence }\end{array}$ & 0 & & $50.5977 \%$ \\
\hline COST VALUE & $3,011,989,933$ & & \\
\hline
\end{tabular}

Source: Appalachian Power Valuation Calendar Year 1998, 1999

\subsubsection{INCOME APPROACH}

The current WV income approach to valuation of AP plants in WV is based on historical earnings for five previous years as depicted in table 6. Earnings are analyzed to determine percentage increases or decreases over this time period. Operating revenue minus expenses yields net operating income; the most recent year's net income is averaged with the previous four years to compute average net income. This average income is capitalized based on the WACC formula (as discussed in section 5.1). Working capital is deducted from the capitalized income to arrive at the current income value of the plant. The only difference between the WV method 
and a traditional income approach is that WV utilizes historical income. In a deregulated environment, this income would be based on income projections derived from the projected market price for electricity. Theoretically, the values should be similar.

Table 3.2. Income approach for AP assets

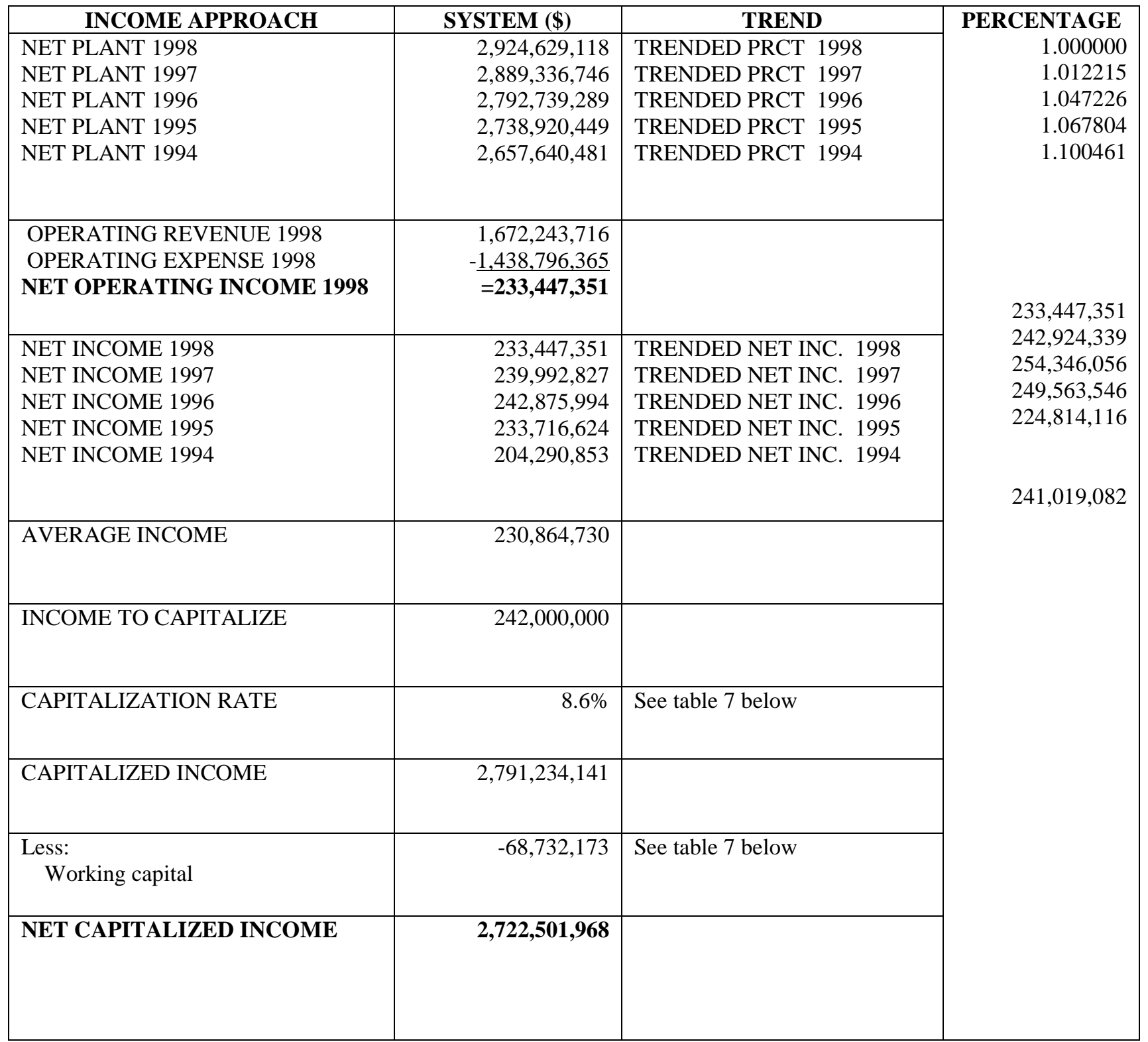

Source: Appalachian Power Valuation Calendar Year 1998, 1999 
Table 6.3. Capitalization rate and working capital

\begin{tabular}{|lr|}
\hline \multicolumn{2}{|c|}{ BAND OF INVESTMENT CAP. RATES } \\
\hline Common & $1,103,551,868$ \\
Preferred & $41,668,700$ \\
Short Term Debt & $76,400,000$ \\
Long Term Debt & $1,552,454,808$ \\
TOTAL & $\mathbf{2 , 7 7 4 , 0 7 5 , 3 7 6}$ \\
Equity Rate & $11.00 \%$ \\
Preferred Rate & $6.75 \%$ \\
Short Term Debt & $6.00 \%$ \\
Long Term Debt Rate & $7.19 \%$ \\
CAPITALIZATION RATE & $\mathbf{8 . 6 \%}$ \\
\multicolumn{2}{|c|}{ WORKING CAPITAL } \\
\hline \multicolumn{2}{|c|}{ (30 DAYS OF OPERATING COSTS) } \\
\hline OPERATION \& MAINTENANCE EXPENSE $1,127,902,156$ \\
LESS: PURCHASED POWER & $-303,116,085$ \\
NET EXPENSES & $=824,786,071$ \\
\hline 1/12 NET EXPENSES & $\mathbf{6 8 , 7 3 2 , 1 7 3}$ \\
\hline
\end{tabular}

Source: Appalachian Power Valuation Calendar Year 1998, 1999

\subsubsection{STOCK AND DEBT APPROACH}

The WV stock and debt approach is based upon the accounting equation that the value of the assets equals the value of the liabilities plus net worth. Market values of the longterm debt, current and deferred liabilities, and capital stock are estimated, and the sum of these amounts is held to equal the value of the total AP assets located in WV. As depicted in table 7, the value of the total corporate assets includes nontaxable assets; therefore, value allocations and deductions must be made to arrive at a value estimate for the unitary property. These value adjustments should be made on the basis of the value the securities market places on the deductible assets 
Table 6.4. Stock \& debt approach for AP assets

\begin{tabular}{|c|c|c|c|c|}
\hline \multicolumn{5}{|l|}{ STOCK \& DEBT APPROACH } \\
\hline Stock Value & & & & $+1,450,000,000$ \\
\hline Preferred Stock & & & & $+\quad 42,768,700$ \\
\hline Long-Term Debt & & & & $+1,638,70,000$ \\
\hline Current Liabilities & & & & $+412,224,941$ \\
\hline Gross Stock \& Debt & & & & $=3,543,693,491$ \\
\hline Less: Non-operating property & @ 14.3\% (see below) & & & $-\quad 506,748,191$ \\
\hline Stock \& Debt Value & & & & $=3,036,945,450$ \\
\hline STOCK VALUATION & \# OF SHARES & AVERAGE PRICE & VALUE & \\
\hline Parent Company Stock Value & $190,800,00$ & 42 & $+8,013, \overline{600,000}$ & Total \\
\hline Utility Stock \% & & & $\begin{array}{r}* 18.7 \%(\text { see } \\
\text { below) }\end{array}$ & \\
\hline \multirow[t]{2}{*}{ Utility Stock Value } & & & $=1,498,543,200$ & \\
\hline & NET EARNINGS & $\underline{\text { P/E RATIO }}$ & & \\
\hline \multirow[t]{2}{*}{ Utility Stock Value } & $117,249,312$ & 12 & $=1,406,991,744$ & \\
\hline & & SAY & $=1,450,000,000$ & Net Value \\
\hline \multicolumn{5}{|l|}{$\begin{array}{l}\text { LONG TERM DEBT } \\
\text { VALUATION }\end{array}$} \\
\hline \multirow[t]{2}{*}{ Market Value of Debt-reported } & & $7.19 \%$ & $=1,638,700,000$ & \\
\hline & INTEREST EXPENSE & DEBT RATE & & \\
\hline \multirow[t]{5}{*}{ Market Value of Debt-calculated } & $56,296,499$ & $7.50 \%$ & $750,619,987$ & \\
\hline & $45,578,689$ & $6.75 \%$ & $675,239,837$ & \\
\hline & $15,875,500$ & $5.50 \%$ & $288,645,455$ & \\
\hline & $=117,750,688$ & $6.87 \%$ & $=1,714,505,278$ & \\
\hline & SAY & $7.19 \%$ & $=1,638,700,000$ & \\
\hline \multirow{5}{*}{$\begin{array}{l}\text { UTILITY STOCK EARNINGS } \\
\%\end{array}$} & & PARENT & UTILITY & PECENTAGE \\
\hline & 1998 & $536,200,000$ & $95,956,012$ & $17.9 \%$ \\
\hline & 1997 & $620,400,000$ & $113,508,000$ & $18.3 \%$ \\
\hline & 1996 & $587,400,000$ & $117,751,000$ & $20.0 \%$ \\
\hline & & & SAY & $18.7 \%$ \\
\hline \multirow[t]{4}{*}{ NON-OPERATING } & & NON-OPERATING & TOTAL & PERCENTAGE \\
\hline & Income influence & $5,959,079$ & $242,000,000$ & $2.5 \%$ \\
\hline & Cost Influence & $504,151,978$ & $3,516,141,911$ & $14.3 \%$ \\
\hline & & & SAY & $14.3 \%$ \\
\hline STOCK \& DEBT VALUE & & & & $=3,036,945,450$ \\
\hline
\end{tabular}

Source: Appalachian Power Valuation Calendar Year 1998, 1999

\subsection{CURRENT APPALACHIAN POWER VALUES}

The three valuations of AP assets conducted by the West Virginia Tax Department result in the following values:

- Cost Value (Regulated): \$3,011,989,933 
- Income Value: $\$ 2,722,501,968$

- Stock \& Debt Value: $\$ 3,036,945,450$

The State of West Virginia Property Tax Division, Special Properties Section (Appalachian Power Valuation Calendar Year 1998, 1999), contains the value of AP assets in West Virginia. These assets include the same AP plants listed below in the comparable sales and replacement cost tables. AP plants in West Virginia (for this example) are valued using the cost approach (as a regulated utility), income approach, and stock \& debt approach. West Virginia utilizes the unitary approach so that all AP plants are valued as a unit. The resulting taxes are divided among the appropriate taxing jurisdictions. The cost approach used for a "regulated" plant indicates a combined value of $\$ 3,012$ million dollars. The income approach used an 8.67\% capitalization rate and indicated an "Income Value" of $\$ 2,722$ million dollars for these power plants. The Stock \& Debt Approach value for these plants is $\$ 3,037$ million dollars.

\subsection{COMPARABLE SALES AND REPLACEMENT COST APPROACHES}

The remaining two valuation methods, comparable sales \& replacement cost, are based on analyses of recent power plant sales and published data from the Energy Information Administration (EIA), respectively.

\subsubsection{COMPARABLE SALES}

In testimony before the public Service Commission of West Virginia, Paul Chernick based his analysis of West Virginia utility assets on the actual sales of generating assets (Chernick, 1999). His estimates for AP plants are as follows:

- High quality coal plants at $\$ 950 / \mathrm{kW}$ : Amos and Mountaineer.

- Medium-quality coal plants at $\$ 600 / \mathrm{kW}$ : Philip Sporn unit 5 and Clinch River 
- Low Quality coal plants at \$400/kW: Glen Lyn, Kanawha River, and Philip Sporn units 1-4.

- Pumped storage at $\$ 490 / \mathrm{kW}$ : Smith Mountain

- Run of River Hydro at $\$ 1000 / \mathrm{kW}$ : small hydro unit.

Comparable Sales cost estimates for AP plant capacity in West Virginia are contained in table 9. The total market value of AP plant capacity is estimated to be $\$ 4,474$ million, or a weighted average of $\$ 773 / \mathrm{kW}$. Assuming generation plants are allocated among jurisdictions, based on average demand, then the West Virginia Share of this value is $\$ 1,830$ million.

Table 6.5. Comparable sales approach for AP assets

\begin{tabular}{|c|c|c|c|}
\hline \multicolumn{4}{|c|}{ Comparable Sales Estimate of Appalachian Power Asset's (WV) } \\
\hline Generator & Capacity (MW) & $\$ / \mathrm{kw}$ & Value (millions) \\
\hline Amos & 2032.8 & 950 & 1,931 \\
\hline Mountaineer & 1300 & 950 & 1,235 \\
\hline Philip Sporn Unit 5 & 138.6 & 600 & 83.16 \\
\hline Clinch River & 690 & 600 & 414 \\
\hline Glen Lyn & 325 & 400 & 130 \\
\hline Kanawha River & 390 & 400 & 156 \\
\hline Philip Sporn Unit 1-4 & 138.6 & 400 & 64.96 \\
\hline Smith Mtn. PS Hydro & 565 & 490 & 276.85 \\
\hline Run of River Hydro & 183 & 1000 & 182.90 \\
\hline TOTALS & $5 \overline{786.6}$ & $\$ 773$ & \\
\hline Comparable Sales Va & aluation Total: & & 4,474 Million \\
\hline
\end{tabular}

\subsubsection{REPLACEMENT COST APPROACH}

In estimating replacement cost for a plant, the average cost per $\mathrm{kW}$ is used for construction of an equivalent capacity gas-fired turbine unit known as Combined Cycle Gas Turbine or CCGT (Pifer, 1999). Based on data from Gas Turbine World 1997 Handbook and corroborated with data from the Gas Turbine World 1998-99 Handbook, Howard W. Pifer concluded that the EIA projects a cost of $\$ 445 / \mathrm{kW}$ for a CCGT plant. Depicted in table 10 are 
the AP generators, capacity, estimated $\$ / \mathrm{kw}$ and the total value in dollars. The two components for developing the capital costs of new CCGT capacity are: the turnkey costs, and "soft" costs such as cost for land, infrastructure and interconnection with the electric grid.

Table 6.6. Replacement cost approach for AP assets

\begin{tabular}{|c|c|c|c|}
\hline \multicolumn{4}{|c|}{ Replacement Cost Estimate of Appalachian Power Asset's (WV) } \\
\hline Generator & Capacity (MW) & $\$ / \mathrm{kw}$ & $\underline{\text { Value (millions) }}$ \\
\hline Amos & 2032.8 & 445 & 904.596 \\
\hline Mountaineer & 1300 & 445 & 585 \\
\hline Philip Sporn Unit 5 & 138.6 & 445 & 62.37 \\
\hline Clinch River & 690 & 445 & 310.50 \\
\hline Glen Lyn & 325 & 445 & 146.25 \\
\hline Kanawha River & 390 & 445 & 175.5 \\
\hline Philip Sporn Unit 1-4 & 138.6 & 445 & 73.08 \\
\hline Smith Mtn. PS Hydro & 565 & 445 & 254.25 \\
\hline Run of River Hydro & 183 & 445 & 82.305 \\
\hline TOTALS & $5 \overline{786.6}$ & & \\
\hline \multicolumn{3}{|c|}{ Replacement Cost Valuation Total: } & 1,784 Million \\
\hline
\end{tabular}

Source: Pifer, 1999.

The \$1,784 million dollar replacement cost for all of West Virginia AP assets is significantly lower than the $\$ 4,474$ million dollar estimate based on comparable sales data. The replacement cost data should not contain any intangibles whereas the comparable sales cost will contain intangible value.

\subsection{SUMMATION OF VALUES}

Information contained in table 11 indicates the valuation difference among the five approaches. The least cost value is the replacement cost as opposed to the higher cost of the comparable sales value. This difference can be defined by the existence of intangible value in the comparable sales method of valuation. Other added value in the comparable sales may also reflect the current market conditions in which power plant sales are taking place. The regulated 
cost value and the stock and debt value are very close. The income value interestingly reflects the difference between the replacement value and the comparable sales value. This could make the income approach the best indicator of value for the implied bundle of intangible assets.

Table 6.7. Comparative values for AP assets

\begin{tabular}{|c|l|r|l|l|l|}
\hline \multicolumn{7}{|c|}{ Valuation of Appalachian Power Plant Generation Assets in West Virginia } \\
(in millions of dollars) \\
\hline $\begin{array}{l}\text { Combined } \\
\text { Capacity } \\
\text { (MW's) }\end{array}$ & $\begin{array}{l}\text { Cost } \\
\text { (Regulated) }\end{array}$ & Income & $\begin{array}{l}\text { Replacement } \\
\text { Cost }\end{array}$ & $\begin{array}{l}\text { Comparable } \\
\text { Sales }\end{array}$ & $\begin{array}{l}\text { Stock } \\
\& \text { Debt }\end{array}$ \\
\hline $5,786.6$ & $\$ 3,012$ & $\$ 2,722$ & $\$ 1,784$ & $\$ 4,474$ & $\$ 3,037$ \\
\hline
\end{tabular}




\section{Chapter 7}

\section{Summary \& Conclusions}

\subsection{SUMMARY}

The four valuation methods; income, stock and debt, replacement, and comparable sales, were examined in theory and practice with the regulated cost approach to valuation used as a check. All four methods are common appraisal methods used for ad valorem taxation purposes. In the case of West Virginia, and many other states, property tax reform will be necessary because of competitive costs and the concern for maintaining tax revenue neutrality. Competitive costs will be an important factor especially under deregulation, which brings competition from out-of-state electricity providers. Differential tax treatments with bordering states will affect the price of electricity to customers. Also, competition will exist between other providers within West Virginia such as the non-taxable municipal and federally owned utilities. Currently, West Virginia has put their deregulation plans on hold while it studies a variety of issues to include tax reform. One of the most important considerations in the choice of valuation method is the use of intangible assets and their resulting effect on total value and indirectly on tax revenue.

The ability to compete across state lines while containing costs is a regional issue. The concept of an equitable revenue neutral tax structure is intended to retain a level of tax revenue for taxing jurisdictions. Meanwhile the concept of a level playing field is intended to impose equal treatment among all types of power generators as well as competing out-of-state electricity providers. Because they are no longer allowed to recover costs through the regulated price of electricity, electricity generators will no longer be guaranteed collectors of taxes. 
The only aspect of the electricity industry to be deregulated is the generation sector; transmission and distribution will still be regulated. Instituting a consumption tax on the customer could make up for the loss in tax revenue that results from lower plant valuations. A consumption tax will take place at the distribution level and not the generation level. Since, by definition, distribution takes place within the state, such taxes would not be in violation of the interstate commerce act. This is one way to make up for the loss in tax revenue. But it does not solve the problem of power plants in adjoining states being valued differently. This can seriously affect the ability to compete within the state.

In litigation cases, most school districts will probably seek to rely upon the comparable sales approach to valuation to determine property tax values for utility assets. This approach would create the largest amount of tax revenue compared to other valuation approaches. The primary drawback with this method is that it inherently contains the value of the intangible assets related to the plant. Most power plants are not purchased for their physical (tangible) assets only but by their demonstrated market power, physical location (access to transmission line or fuel sources), brand name/reputation, demonstrated management, or power purchase contracts. Currently, the state of West Virginia is phasing out taxation of intangibles and will have to reassess its valuation techniques.

With regard to intangibles, three of the valuation methods require further study and analysis. When using the comparable sales approach, comparable properties are often sold in a transaction that includes intangible assets and rights. The value of those intangible assets and rights, as well as the value of assets other than the comparable property, must be removed from the sale price before the sale is compared to the subject property. Anyone valuing property can use any of the three additional approaches (cost, income, and market) to value those nontaxable 
intangible assets and rights when necessary. If the subject property is part of the sale of a business enterprise, the appraiser may wish to examine transaction documents that contain an allocation of the purchase price to the various component assets. This allocation may or may not be made based upon the fair market value of the various components.

If an income stream is generated in part by intangible assets and rights, then it may be necessary to either attribute sufficient income to provide a return of and on the intangible rights or remove the value of the intangible assets and rights from the income indicator after the income stream has been capitalized or discounted to present value. A business may have valuable intangible assets and rights even though the business may not generate sufficient income to produce an adequate rate of return for the utility generator in question. In contrast, the replacement cost approach serves as the best indicator of physical (tangible) value. The cost efficiencies associated with gas turbine technology make it the best replacement choice in a competitive market as well as the best choice for peaking power or additional capacity as discussed in chapter 3. Most new power plants are based on gas turbine technology for their base load.

The Stock \& Debt Approach depends on the assumption that capital markets accurately value financial claims, that is, that capital market prices reflect the intrinsic economic values of the securities traded. Market efficiency refers to informational efficiency not operational efficiency in how quickly and accurately a market processes trades. An obvious limitation to the stock and debt approach is that it cannot be applied to value the property of a firm whose common stock is not publicly traded.

Determining the value of deregulated utility assets is relatively new and the precedence for using other methodologies is not yet set. The comparative sales approach is an inappropriate 
method to value utility assets in a deregulated climate. This is due to the tendency of these sales to be overvalued because of forced divestitures and investor attempts to expand markets through purchases. It is difficult to omit this type of analysis in court cases involving judges, juries, and less well informed attorneys because of the common use of this method in both residential and commercial property valuations. Another aspect to the drawbacks of this method is that it is based on nameplate capacity and not operating capacity. Many plants may be valued for their potential and not their competitive operating levels.

Mandatory divestiture could result in significant losses of tax revenues for state and local communities. Electric utilities pay billions of dollars in state and local taxes ( $\$ 13.9$ billion nationwide in 1996) that are included in electricity rates. With the historically high tax rates imposed on utilities, a prescribed sell-off of assets could have a devastating effect on tax receipts, especially if they are sold to utility companies that have paid less in taxes.

The income approach assumes that buyers and sellers of property base their valuations on the income that a property is expected to produce. The critical variables in the income approach are the expected future income to be capitalized or discounted and the rate of capitalization/discount. The income is based on a forecast of expected gross income and a forecast of expected future operating expenses. The expected income stream of a power plant used in the income approach is based on several assumptions. For a competitive electricity market these assumptions will be based on the market equilibrium price and any fluctuations in the customer base or competitive market can affect the value of the asset. In a competitive environment the most efficient way to produce electricity is the method that maximizes the difference between the value of outputs and the value of inputs. Theoretically, the income 
approach should be the preferred valuation method especially with the transitional issues associated with the competitive market.

\subsection{CONCLUSION}

If the value of deregulated utility assets is for the purpose of buying or selling utility assets, then the income approach should be preferred and the comparable cost approach used as a check. The "highest and best use" of the plant being valued should be considered in choosing the proper valuation method. For the purposes of ad valorem taxation, the plant is assumed to be utilizing all assets for the purpose of producing and selling electricity. In this case the income approach could be used for states that tax tangible and intangible values.

The cost approach (replacement cost) typically includes only the tangible taxable property so may not require removal of the intangible assets or rights. However, this does not mean that the value as estimated using the cost approach sets a ceiling on values estimated using the income approach or comparable sales approach, or that there is a restriction on using the most appropriate method on arriving at fair market value. As with the comparable sales approach, the replacement cost approach is also based on nameplate capacity. A plant valued with this method could potentially be overvalued because it $\mathrm{m}$ ay not operate at its full potential in a competitive market.

The court cases discussed indicate that an alternative approach may be to first use the income approach to value utility assets, and then utilize the results from the comparable sales and replacement cost approaches. The difference between the replacement cost value and the comparable sales cost value or income approach value could be a good indicator of the value of the intangible assets. This is based on the fact that power plant purchases inherently contain the 
intangible assets that make the purchase desirable and the replacement cost is based on the physical (tangible) assets.

In valuing utility property it is necessary to reconcile the values arrived at from the different approaches. In theory, each approach to value should yield the same indication of value. In reality, it is rare for any two approaches to yield the same value. Variations occur because of the lack of adequate and reliable data as well as subjectivity when making adjustments. And finally, the inclusion of intangible assets with the tangible property can comprise the difference between values that have been arrived at. If the value derived from the income approach is substantially higher than the value from the cost replacement approach then the assumption is that the intangible assets make up the difference.

\subsection{FURTHER RESEARCH REQUIRED}

The issue of valuation for property tax purposes is important and requires further study. The solution may be to institute a consumption tax but meanwhile valuation continues to take place and some methods are being challenged in the courts. Valuation for deregulated utilities is a hot topic in the power industry, accounting profession, taxation associations, with court cases, and state legislators. Further research at the thesis or doctoral level could be conducted. As power plant sales and divestitures increase, an econometric analysis for the comparable sales approach might provide some insight into valuation. Research could also be conducted into a method that could be used to separate out the intangible value of a power plant. This would be

helpful to states that do not tax intangible property. Another area for research could be the effect of a consumption tax on the market. 


\section{References Cited}

American Public Power Association (APPA). State Restructuring-State Tax Initiatives Related to Restructuring. http://www.appanet.org July 2000

Appalachian Power Valuation Calendar Year 1998. West Virginia StateTax Department. 2 Sep 1999

Assessor's Handbook 541. State of California, Office of Property Tax and Revenue. May 2000

Anderson, Susan E.. The State Tax Considerations of Electric Utility Deregulation. Journal of State Taxation. Vol 18 No. 2, Fall 1999. pg. 17-29.

Baxter, L. \& E. Hirst. Estimating Potential Stranded Commitments for U.S Investor-Owned Electric Utilities, ORNL/CON-406, Oak Ridge National Laboratory, Oak Ridge, Tn 1995

Bizyak, Melissa. Capitalization Rate Versus Discount Rate. Grossman, Yanak \& Ford (GYF), Undated.

Blacconiere, W. G., Marilyn F Johnson, and Mark S. Johnson. Market Valuation and Deregulation of Electric Utilities. Working Paper. June 17, 1999

Bonbright, James C. The Valuation of Property. New York. McGraw Hill Book Co

Bonbright, J., A. Danielson, and D. Kamerschen Principles of Public Utility Rates, 2nd ed., Public Utility Reports, Inc., Arlington, VA. 1988.

Borenstein, Severin, James Bushnell, and Christopher R. Knittel. 1999. Market Power in Electricity Markets: Beyond Concentration Measures. The Energy Journal, Vol. 20, No. 4, 1999

Chen, Houng-Yhi. Valuation Under Uncertainty. Journal of Financial and Quantitative Analysis, Volume 2, Issue 3, Sep. 1967, pg. 313-325

Chernick, Paul, Resource Insight, Inc. Direct testimony on Behalf of the Consumer Advocate Division of the Public Service Commission of West Virginia. Case No. 98-0452-E-GI. July 7, 1999.

Coggins, Jay S. An Arbitrage-Free Approach to Quasi-Option Value. Journal of Environmental Economics and Management 35, 103-125, 1998.

Coopers and Lybrand L.L.P. Electric \& Gas Industries: Deregulation Raises State and Local Tax Concerns. 1997. 
Copeland, T., and J. Murin.. Valuation: Measuring and Managing the Value of Companies. John Wiley \& Sons, New York. 1990

Deloitte and Touche. Federal, State and Local Tax Implications of Electric Utility Industry Restructuring. Dallas Texas, October 1996

Eckert, J., ed. Property Appraisal and Assessment Administration. Chicago, Ill.: The International Association of Assessing Officers. 1990.

Edison Electric Institute. Competition in Electricity Markets: The Case Against Forced Divestiture. http:www.eei.org/issues/comp_reg/divest-3.htm. July, 1999

Ellsworth, Richard K. Valuation Analysis for Independent Power Project. Journal of Energy Engineering, Vol. 120, No.2 August 1994.

Energy Information Administration (EIA). The Changing Structure of the Electric Power Industry 2000: An update. DOE/EIA-0562(00). October 2000.

Grossman, Robert J. "What is a Discount Rate?" Grossman, Yanak \& Ford (GYF). 2000.

Hall, Bronwyn H., The Stock Market's Valuation of R\&D Investment during the 1980's. The American Economic Review, Volume 83, Issue 2. May 1993 259-264

Hayward, David L. and Michael R. Schmidt. Valuing an Electric Utility: Theory and Application. Public Utilities Reports, Inc. Vienna, Virginia. 1999

Henszley, Benjamin N. Going Concern After Concord Control, Inc. Taxes, November 1983, pg. 699.

Hirst, Eric., Lester Baxter, and Stan Hadley. Transition Cost Issues for US Electricity Utilities. Annual Review of Energy and the Environment, 1997. 22:119-54

Isard, Walter. The General Theory of Location and Space-Economy. Quarterly Journal of Economics, Volume 63, Issue 4. Nov. 1949, 476-506.

Joskow, Paul L. Restructuring, Competition and Regulatory Reform in the U.S. Electricity Sector. The Journal of Economic Perspectives, Volume 11, Issue 3 (Summer, 1997), 119-138.

Krueger, A.O., 1974. The political economy of the rent-seeking society. American Economic Review 64, 291-303.

Levin, Rich and Bill Driscoll. Electric Utility Deregulation and its Potential Tax Impact on Ohio School Districts with Electric Generating Plants. Report prepared for the Ohio School Boards Association. August 9, 1996.

Mahaffey, Doris. Re-Assessing Ohio’s Public Utility Property Tax in an era of Public 
Utility Restructuring. Ohio Legislative Budget Office (LBO). Undated.

Manning, Lloyd R. Valuing the Small Business. Todd Publishing , Inc., Scottsdale, Arizona. 1993, Pgs 6-7.

Mobley III, T. Alvin. Defining and Allocating Going-Concern Value Components. Appraisal Journal. 65:323-33-, October 1997.

Moorhouse, John C. Competitive Markets for Electricity Generation. The CATO Journal Vol 14. No. 3. Winter 1995.

Murray, Jacqueline Phillips. Real Property Taxation of Utility Generation Facilities. Letter, undated. Law Firm of Crane, Greene \& Parente, Albany. N.Y.

Pifer, Howard W. III on Behalf of Monongahela Power Company and the Potomac Edison Company dba Allegheny Power. Direct testimony before the West Virginia Public Service. Case No. 98-0452-E-GI. July 6, 1999.

Public Service Commission, State of Georgia. Tax Implications of Restructuring Georgia's Electric Industry. July 14, 1997. www.psc.state.ga.is/electric/Reports.

Rabianski, Joseph S. Going-Concern Value, Market Value, and Intangible Value. Appraisal Journal, April 1996. pgs 183-194.

Reilly, Robert F. and Manoj P Dandekar. Valuation of Intangible Contract Rights. The CPA Journal, June 1997.

Ruff, Larry. Competitive Electricity Markets : Why They Are Working And How To Improve Them. 12 May 1999. Harvard Electricity Group. http://ksgwww.harvard.edu/hepg/FPRuff599.htm. (Accessed: Nov 15, 2000)

Schneider, Steven P. Evaluating power plant property taxes under deregulation. Public Utilities Fortnightly. Arlington, Va. March 1, 1998.

Schneider, Steven P. Deregulation. Journal of Multistate Taxation and Incentives. August 1999.

Shepherd, William G. Market Power in the Electric Utility Industry: An Overview. National Council on Competition in the Electric Industry. November 1997.

Shogren, Jason F. and Thomas D. Crocker. Risk and Its Consequences. Journal of Environmental Economics and Management 37, 44-51, 1999.

Simonds, Richard R. Accuracy of the Yield and Direct Capitalization Methods: A Twenty-Year Empirical Study of the Electric Utility Industry. Assessment Journal. July/August 1999. 
State Electricity Profiles 2000 - West Virginia.

http://www.eia.doe.gov/cneaf/electricity/st_profiles/west_virginia/wv.html.

(Accessed: Oct 9, 2000)

Tollison, R. Rent-seeking, A survey. Kyklos 35, pg. 575-602, 1982

Torries, Thomas F. Handbook of Mineral Project Evaluation. Society of Mining, Metallurgy, and Exploration, Inc. November 1996.

West Virginia Public Service Commission Report. Public Service Commission of the State of West Virginia, pg. 14, 1997.

Youngman, Joan. Legal Issues In Property Valuation and Taxation: Cases and Materials. The International Association of Assessing Officers. 1994 